\title{
MICROBIALITE FORMATION IN SEAWATER OF INCREASED ALKALINITY, SATONDA CRATER LAKE, INDONESIA
}

\author{
GERNOT ARP, ANDREAS REIMER, AND JOACHIM REITNER \\ Geowissenschaftliches Zentrum der Universität Göttingen, Abteilung Geobiologie, Goldschmidtstraße 3, D-37077 Göttingen, Germany \\ e-mail: garp@gwdg.de
}

Aвstract: The crater lake of the small volcanic island Satonda, Indonesia, is unique for its red-algal microbial reefs thriving in marinederived water of increased alkalinity. The lake is a potential analogue for ancient oceans sustaining microbialites under open-marine conditions. Current reef surfaces are dominated by living red algae covered by non-calcified biofilms with scattered cyanobacteria and diatoms. Minor $\mathrm{CaCO}_{3}$ precipitates are restricted to the seasonally flooded reef tops, which develop biofilms up to $500 \mu \mathrm{m}$ thick dominated by the cyanobacteria Pleurocapsa, Calothrix, Phormidium, and Hyella. Microcrystalline aragonite patches form within the biofilm mucilage, and fibrous aragonite cements grow in exopolymer-poor spaces such as the inside of dead, lysed green algal cells, and reef framework voids. Cementation of lysed hadromerid sponge resting bodies results in the formation of "Wetheredella-like" structures.

Hydrochemistry data and model calculations indicate that $\mathrm{CO}_{2}$ degassing after seasonal mixis can shift the carbonate equilibrium to cause $\mathrm{CaCO}_{3}$ precipitation. Increased concentrations of dissolved inorganic carbon limit the ability of autotrophic biofilm microorganisms to shift the carbonate equilibrium. Therefore, photosynthesis-induced cyanobacterial calcification does not occur. Instead, passive, diffusioncontrolled EPS-mediated permineralization of biofilm mucus at contact with the considerably supersaturated open lake water takes place. In contrast to extreme soda lakes, the release of $\mathrm{Ca}^{2+}$ from aerobic degradation of extracellular polymeric substances does not support $\mathrm{CaCO}_{3}$ precipitation in Satonda because the simultaneously released $\mathrm{CO}_{2}$ is insufficiently buffered.

Subfossil reef parts comprise green algal tufts encrusted by microstromatolites with layers of fibrous aragonite and an amorphous, unidentified $\mathrm{Mg}-\mathrm{Si}$ phase. The microstromatolites probably formed when Lake Satonda evolved from seawater to $\mathrm{Ca}^{2+}$-depleted raised-alkalinity conditions because of sulfate reduction in bottom sediments and pronounced seasonality with deep mixing events and strong $\mathrm{CO}_{2}$ degassing. The latter effect caused rapid growth of fibrous aragonite, while $\mathrm{Mg}-\mathrm{Si}$ layers replaced the initially Mg-calcite-impregnated biofilms. This could be explained by dissolution of siliceous diatoms and sponge spicules at high $\mathrm{pH}$, followed by Mg-calcite dissolution and Mg-silica precipitation at low $\mathrm{pH}$ due to heterotrophic activity within the entombed biofilms.

\section{INTRODUCTION}

Normal-marine settings today sustain microbialite formation only in exceptional cases. There is only one known example of lithifying stromatolites (Bahamas) in an open marine setting of normal seawater salinity (Dravis 1983; Dill et al. 1986; Reid et al. 2000; Visscher et al. 2000). However, many marine fossil microbialites differ from the agglutinated Bahamian stromatolites in that they contain less trapped particles and substantially more in situ precipitated carbonate (Gebelein 1976; Grotzinger 1990; Riding 1991a, 2000)_similar to the stromatolites of the nonmarine type locality (Kalkowsky 1908; Paul and Peryt 1999). One reason for this discrepancy between recent and pre-Tertiary marine carbonate sedimentation is probably a change in ocean chemistry. Seawater chemistry changed through time not only with regard to the $\mathrm{Mg} / \mathrm{Ca}$ ratio (Wilkinson 1979; Riding 1982; Sandberg 1983; Wilkinson et al. 1985; Wilkinson and Given
1986) but also in its entire major ion composition (Spencer and Hardie 1990; Hardie 1996; Arp et al. 2001; Lowenstein et al. 2001).

Nonetheless, the significance of absolute ion concentrations, alkalinity, and $\mathrm{CaCO}_{3}$ supersaturation in microbialite formation remains a matter of discussion (e.g., Kempe and Kazmierczak 1990a, 1990b, 1994; Grotzinger 1990; Knoll et al. 1993; Grotzinger and Knoll 1995). This is especially true for $\mathrm{Ca}^{2+}$ and alkalinity because both are strongly affected by biological processes, such as active $\mathrm{Ca}^{2+}$ removal by cellular ion pumps and $\mathrm{HCO}_{3}$ release from bacterial sulfate reduction. Weathering and plate tectonic processes are two additional factors affecting seawater composition. Furthermore, changes of $\mathrm{pCO}_{2}$ in the atmosphere (see Royer et al. 2001 for review) have to be taken into consideration when discussing constraints on ancient seawater alkalinities and $\mathrm{CaCO}_{3}$ mineral supersaturation (e.g., Mackenzie and Pigott 1981; Kempe and Degens 1985; Mackenzie and Agegian 1989; Grotzinger 1990, 1994; Morse and Mackenzie 1998). Thus, in situ calcifying biofilms and microbial mats forming in modified seawater are of special interest as potential analogues for fossil microbialites of open marine settings. Knowledge of their formation processes may provide indications for the reconstruction of the ambient seawater chemistry.

A quasi-marine alkaline lake sustaining microbialite formation has been described from Satonda (Kempe and Kazmierczak 1990a, 1990b, 1993; Kempe et al. 1996, 1997), a small volcanic island north of Sumbawa, Indonesia (Fig. 1). These microbialites form a part of the red-algal-microbialite reefs, which occur at protrusions of the rocky lake shore (Fig. 1). Kazmierczak and Kempe (1990) suggested that the microbialites formed by calcifying cyanobacterial mats and compared them with Paleozoic stromatoporoids. They further argued that this similarity was a reason to believe that early Paleozoic seawater had a higher alkalinity and $\mathrm{CaCO}_{3}$ supersaturation than modern seawater.

The purpose of this paper is to elucidate mechanisms of microbialite formation in seawater of increased alkalinity. We focus on precipitation in recent biofilms in the lake in relation to biofilm structure and seasonal hydrologic cycle in Satonda. Investigation of mechanisms of recent biofilm calcification serves as a basis for exploring the formation of the unique subfossil microbialite. Finally, results of the present study are compared and contrasted with the model of Satonda Lake microbialite formation proposed by Kazmierczak and Kempe $(1990,1992)$ and Kempe and Kazmierczak (1990a, 1990b, 1993).

\section{FACTORS CONTROLLING BIOFILM CALCIFICATION}

Biofilms consist of microbial cells, mainly prokaryotes of several metabolic groups (Van Gemerden 1993), embedded in a highly hydrated mucilage composed of extracellular polymeric substances (EPS) (Decho 1990; Wingender et al. 1999). In contrast to biomineralization in eukaryotic algae and metazoa (Westbroek et al. 1984; Addadi and Weiner 1985; Mann 1988; Lowenstam and Weiner 1989; Simkiss and Wilbur 1989), precipitation in biofilms is rarely controlled by the microorganisms and is regarded as induced or mediated (e.g., Pentecost 1991; Riding 1991a, 2000). Indeed, nonliving organic matter can mineralize without apparent direct involvement of living cells, a process known as "organomineralization" (Trichet and Défarge 1995; Défarge et al. 1996; see also Reitner et al. 1995).

There are three major factors that are significant in biofilm calcification. First, is the initial dissolved inorganic carbon pool and saturation state with respect to $\mathrm{CaCO}_{3}$ minerals. Approximately ten-fold calcite supersaturation 

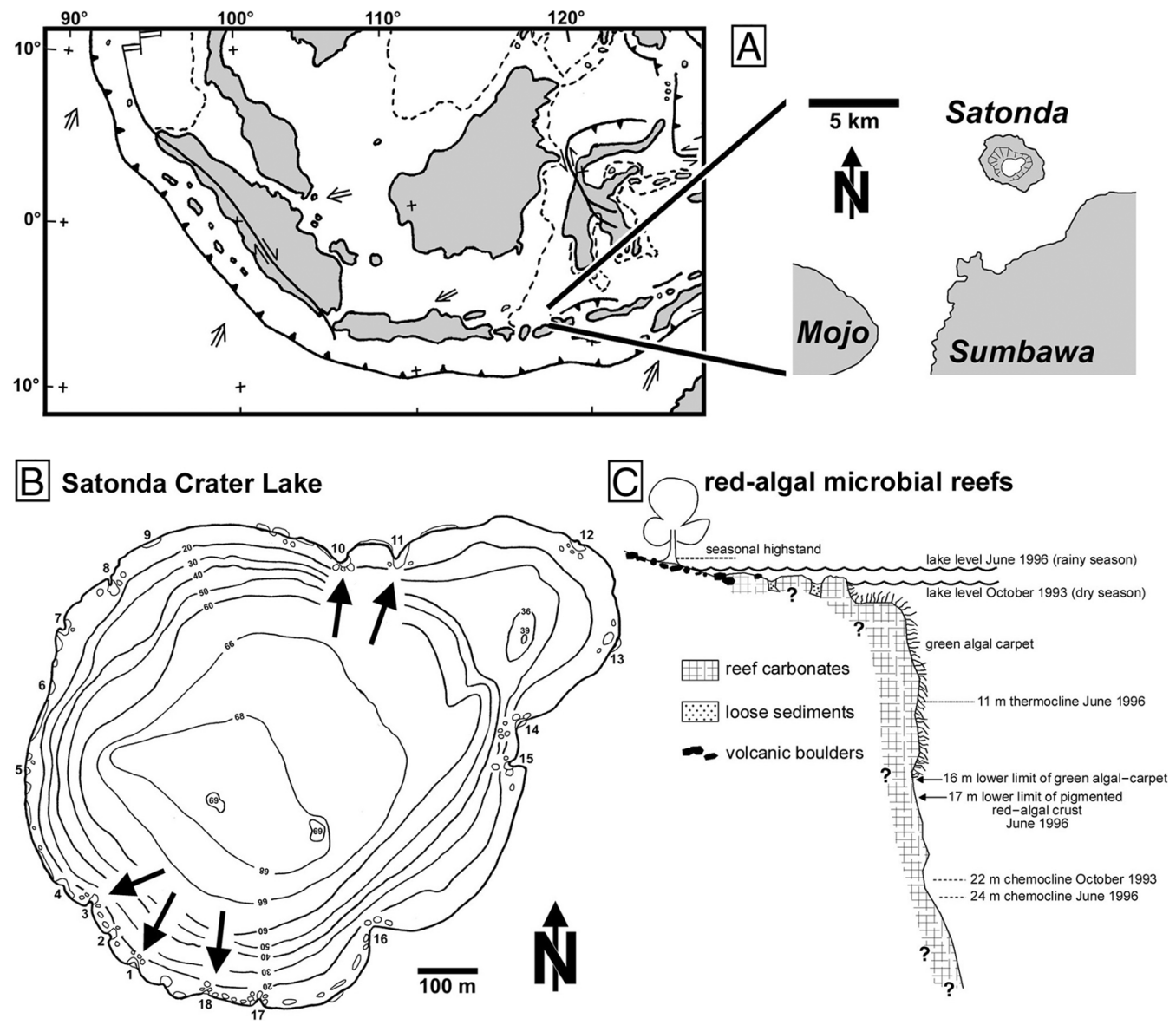

FIg. 1.-A) Location of the Satonda island, north of Sumbawa, Sunda archipelago, Indonesia. B) Bathymetric map of the Satonda Crater Lake (from Kempe and Kazmierczak 1990, modified). Arrows indicate reef sites sampled in this study. C) Schematic section of the red-algal-microbialite reefs. Drawing is not to scale.

(i.e., $\mathrm{SI}_{\mathrm{Cc}}=1.0 ; \mathrm{SI}_{\mathrm{Arag}}=0.86$; for definition of SI see Table 1) seems to be a prerequisite for biofilm calcification (Arp et al. 1999a; Arp et al. 1999b, 2001). This level of threshold supersaturation for $\mathrm{CaCO}_{3}$ precipitation varies in different settings, mainly dependent on the $\mathrm{Mg}^{2+}, \mathrm{SO}_{4}{ }^{2-}$, and $\mathrm{PO}_{4}{ }^{3-}$ concentrations. Starting from the level of initial supersaturation, the effect of carbon fixation by organisms on the $\mathrm{CaCO}_{3}$ supersaturation depends on the concentration of dissolved inorganic carbon (DIC). The same amount of fixed carbon causes a great change in supersaturation in
low-DIC settings, whereas high-DIC settings are almost unaffected (Arp et al. 2001).

The second major factor in biofilm calcification are physiological processes of microorganisms; these processes could alter the carbonate equilibrium and $\mathrm{Ca}^{2+}$ concentration in the microenvironment. Physiological processes capable of inducing $\mathrm{CaCO}_{3}$ precipitation (i.e., temporarily shift the $\mathrm{SI}_{\mathrm{Cc}}$ to values higher than 1.0) are autotrophic $\mathrm{CO}_{2}$ fixation, nitrate reduction and ammonification, sulfate reduction, and coupled sulfate re-

TABLE 1.-Water chemistry of samples from three different water depths that are representative of the three lake water bodies of Satonda Crater Lake, respectively.

\begin{tabular}{|c|c|c|c|c|c|c|c|c|c|c|c|c|}
\hline Sample & Depth & $\mathrm{T}^{\circ} \mathrm{C}$ & $\mathrm{pH}$ & $\mathrm{p} \varepsilon^{\mathrm{a}}$ & Salinity \%o & $\begin{array}{l}\text { Total Alk } \\
\text { meq L }{ }^{-1}\end{array}$ & $\begin{array}{c}\mathrm{DIC}^{\mathrm{c}} \\
\mathrm{mmol} \mathrm{L}^{-1}\end{array}$ & $\underset{\mathrm{mmol} \mathrm{L}^{-1}}{\mathrm{Ca}^{2+}}$ & $\begin{array}{c}\mathrm{Mg}^{2+} \\
\mathrm{mmol} \mathrm{L}^{-1}\end{array}$ & $\mathrm{SI}_{\mathrm{Cc}}{ }^{\mathrm{d}}$ & $\mathrm{SI}_{\text {Arag }}{ }^{\mathrm{d}}$ & $\begin{array}{l}\mathrm{pCO}_{2}{ }^{\mathrm{f}} \\
\mu \mathrm{atm}\end{array}$ \\
\hline \multicolumn{13}{|l|}{ Sampling period October 1993} \\
\hline \multirow[t]{2}{*}{ Mixolimnion (0-22 m) } & $0.1 \mathrm{~m}$ & 30.7 & 8.58 & 4.52 & 31.4 & 4.17 & 3.41 & 4.64 & 42.50 & 1.00 & 0.86 & 282 \\
\hline & $5 \mathrm{~m}$ & 30.9 & 8.59 & 4.38 & 31.4 & 4.15 & 3.38 & 4.58 & 42.58 & 1.00 & 0.86 & 269 \\
\hline Monimolimnion, concentrated layer (22-50 m) & $30 \mathrm{~m}$ & 29.8 & 7.28 & -1.92 & 37.3 & 7.38 & 7.74 & 5.53 & 49.88 & 0.19 & 0.05 & 14791 \\
\hline Monimolimnion, brine $(50-69 \mathrm{~m})$ & $60 \mathrm{~m}$ & 29.4 & 6.94 & -2.94 & 41.7 & 50.43 & 56.45 & 5.93 & 57.58 & 0.68 & 0.54 & 218776 \\
\hline \multicolumn{13}{|l|}{ Sampling period June 1996} \\
\hline \multirow[t]{2}{*}{ Mixolimnion (0-24 m) } & $0.5 \mathrm{~m}$ & 30.6 & 8.50 & 6.31 & 29.4 & 3.97 & 3.33 & 4.55 & 43.57 & 0.92 & 0.78 & 339 \\
\hline & $5 \mathrm{~m}$ & 30.5 & 8.58 & 6.31 & 29.4 & 4.04 & 3.30 & 4.65 & 43.28 & 0.99 & 0.85 & 269 \\
\hline Monimolimnion, concentrated layer (24-51 m) & $30 \mathrm{~m}$ & 29.7 & 7.35 & -2.12 & 37.2 & 7.60 & 7.89 & 5.93 & 51.39 & 0.29 & 0.15 & 12589 \\
\hline Monimolimnion, brine $(51-70 \mathrm{~m})$ & $60 \mathrm{~m}$ & 28.9 & 6.97 & -3.54 & 41.6 & 47.56 & 52.87 & 6.30 & 58.25 & 0.71 & 0.57 & 186209 \\
\hline Standard seawater ${ }^{b}$ & & 25.0 & 8.22 & 8.45 & 35.0 & 2.406 & 2.18 & 10.66 & 55.07 & 0.76 & 0.61 & 417 \\
\hline
\end{tabular}

a Redox intensity $\mathrm{p} \varepsilon=-\log \left\{\mathrm{e}^{-}\right\}$

b Total alkalinity $=$ acid-neutralizing capacity expressed as milliequivalent per liter

${ }^{c}$ Dissolved inorganic carbon DIC $=\left[\mathrm{CO}_{2}(\mathrm{aq})\right]+\left[\mathrm{H}_{2} \mathrm{CO}_{3}\right]+\left[\mathrm{HCO}_{3}^{-}\right]+\left[\mathrm{CO}_{3}^{2-}\right]$

${ }^{\mathrm{a}} \mathrm{SI}_{\mathrm{Cc}}, \mathrm{SI}_{\mathrm{Arag}}$ : Saturation index for calcite and aragonite; $\mathrm{SI}=\log (\mathrm{IAP} / \mathrm{K})$, where $\mathrm{IAP}=$ ion activity product of $\mathrm{Ca}^{2+}$ and $\mathrm{CO}_{3}{ }^{2 \pm s}$, and $\mathrm{K}=$ solubility product of calcite and aragonite, respectively.

e from Nordtrom et al. (1979).

f Partial pressure of carbon dioxide. 
duction-methanotrophy (e.g., Berner 1971; Golubić 1973; Kelts and Hsü 1978; Krumbein 1979; Lyons et al. 1984; Thompson and Ferris 1990; Ritger et al. 1987; Paull et al. 1992; Fortin et al. 1997; Castanier et al. 2000; Peckmann et al. 2001). In biofilms, an increase in supersaturation is facilitated by the reduced diffusion rates within the mucilage.

Finally, the third crucial step in biofilm calcification is the process of formation of seed crystals, which is controlled by the concentration and stereochemical arrangement of acidic groups in EPS (Trichet and Défarge 1995; Arp et al. 1998; Arp et al. 1999a; Arp et al. 1999b, 2001; Kawaguchi and Decho 2001). Disordered complexation of divalent cations, characteristic of many carbohydrate polymers, should inhibit precipitation. By contrast, organic matrices in biomineralizing organisms show well defined carboxylate groups corresponding to the crystal lattice when attached to solid substrates and therefore promote nucleation (Addadi and Weiner 1985; Mann 1988; Lowenstam and Weiner 1989; Simkiss and Wilbur 1989). However, inhibition in many polyanionic organic acids is only temporary (e.g., Sikes et al. 1994) and re-arrangement of the acidic polymers by rotation of exocyclic groups and around the glycosidic linkages (Brant and Christ 1990) is assumed to result accidentially in suitable nucleation sites in biofilm EPS after saturation with divalent cations (Arp et al. 1999a; Arp et al. 1999b).

\section{ENVIRONMENTAL SETTING}

Satonda, a volcanic island $2 \mathrm{~km} \times 3 \mathrm{~km}$ in size, is situated $3 \mathrm{~km}$ north of Sumbawa, Indonesia (Fig. 1). It belongs to the inner part of the 6,000$\mathrm{km}$-long Sunda Island Arc, which is linked to the subduction zone between Sumatra and the eastern Banda Sea. The island shows a central double caldera that formed after the last eruption more than $4000 \mathrm{yr}$ B.P. (Kempe and Kazmierczak 1990a, 1990b, 1993; Kempe et al. 1996, 1997). Initially filled with freshwater, the crater lake was flooded with seawater approximately $3000 \mathrm{yr}$ B.P. Today, there is no connection to the surrounding sea. The lake level remains 1-2 m higher than that of the sea, even during the dry season. High organic input, intense sulfate reduction, and periods of high evaporation changed the marine lake during the last few thousand years into an alkaline meromictic lake (Kempe and Kazmierczak 1990a, 1990b, 1993; Kempe et al. 1996, 1997).

Water-chemistry data are available for the dry season of October 1993 and the end of the wet season of June 1996 (Table 1). The lake level fluctuates in a range of $1 \mathrm{~m}$ between the seasons. In principle, the lake is divided by two chemoclines into an oxygenated mixolimnion, an anoxic upper monimolimnion ("concentrated layer") and an anoxic lower monimolimnion ("brine"). Further detailed water-chemistry data are published in Kempe and Kazmierczak (1993) and Kempe et al. (1996, 1997). Bicarbonate production of the monimolimnion sulfate reduction is partly transferred to the mixolimnion, raising alkalinity to $4.04-4.15 \mathrm{meq} \mathrm{L}^{-1}$ and $\mathrm{pH}$ to 8.6 (Kempe and Kazmierczak 1993). As a consequence, supersaturation of surface waters with respect to calcium carbonate minerals is high (Table $1 ; \mathrm{SI}_{\mathrm{Cc}}=+0.92$ to $+1.00, \mathrm{SI}_{\text {Arag }}=+0.78$ to +0.86$)$ compared to standard seawater $\left(\mathrm{SI}_{\mathrm{Cc}}=+0.76, \mathrm{SI}_{\text {Arag }}=+0.61\right.$; Nordstrom et al. 1979). The salinity of the mixolimnion is $31.4 \%$ in the dry season, and drops slightly to $29.4 \%$ at the end of the rainy season (Table 1). Seasonal rain precipitation lowers $\mathrm{pH}$, alkalinity, and $\mathrm{Ca}^{2+}$ of the surface waters at less than $1 \mathrm{~m}$ depth, but the resulting $\mathrm{CaCO}_{3}$ supersaturation is still high $\left(\mathrm{SI}_{\mathrm{Cc}}\right.$ $\left.=+0.92, \mathrm{SI}_{\text {Arag }}=+0.78\right)$ and only slightly lower compared to the dry season. The $\mathrm{Mg}^{2+} / \mathrm{Ca}^{2+}$ molar ratio of mixolimnion waters varies around 10 , thus favoring calcium carbonate to precipitate as aragonite. With regard to $\mathrm{pCO}_{2}$, the mixolimnion waters are slightly undersaturated as a result of algal photosynthesis, above all by the extensive green algal carpet. Only the surface water $\mathrm{pCO}_{2}(0.5 \mathrm{~m}$ depth $)$ of the rainy season is almost in equilibrium with the atmosphere (Table 1).

The "concentrated layer" of the monimolimnion shows a raised salinity, which is constant between the seasons (Table 1). The $\mathrm{pCO}_{2}$ of the anoxic waters is raised significantly, thereby lowering $\mathrm{pH}$ and $\mathrm{CaCO}_{3}$ supersaturation to levels $\left(\mathrm{SI}_{\mathrm{Cc}}=+0.19\right.$ to $+0.29, \mathrm{SI}_{\mathrm{Arag}}=+0.05$ to +0.15$)$ unfavorable for $\mathrm{CaCO}_{3}$ precipitation (Table 1). The anoxic brines of the lower monimolimnion also show a raised salinity, and also a tremendously high $\mathrm{pCO}_{2}$ and alkalinity, so that $\mathrm{CaCO}_{3}$ supersaturation is raised to an $\mathrm{SI}_{\mathrm{Cc}}=+0.68$ to +0.71 and $\mathrm{SI}_{\mathrm{Arag}}=+0.54$ to +0.57 . None of the parameters of the carbonate system in the monimolimnion varied significantly between October 1993 and June 1996 (Table 1).

\section{MATERIAL AND METHODS}

Samples investigated in this study were taken by SCUBA diving during the dry season in October 1993 (Appendix 1; see Acknowledgments) and shortly after the wet season in June 1996 (Appendix 2). 103 hardpart thin sections of 30 biofilm samples were prepared according to methods in Arp et al. (1998) and Arp et al. (1999a). In addition, 30 conventional thin sections of dried reef-rock samples were prepared for petrographic description. Epifluorescence images were obtained by using a Zeiss Axioplan microscope equipped with a Peltier-cooled VISICAM-color CCD camera (PCO Computer Optics GmbH, Kehlheim) (Manz et al. 2000). Image stacks with a Z spacing of 0.5 or $0.25 \mu \mathrm{m}$ were obtained by using a piezo-mover (Physik Instrumente GmbH \& Co, Waldbronn) attached to a "Plan-Apochromat" $63 \times$ objective (Zeiss, NA $=1.4$ ). Image processing and threedimensional restoration were carried out by using the Metamorph ${ }^{\circledR}$ Imaging software (Universal Imaging Corporation, West Chester, Pennsylvania) and the EPR ${ }^{\mathbb{N}}$ deconvolution software (Scanalytics, Billerica, Massachusetts). Conventional light microscopy was carried out using the same microscope.

The chemical composition $(\mathrm{Ca}, \mathrm{Mg}, \mathrm{Sr}, \mathrm{Si}$ ) of three samples (including subfossil carbonates, red algal-foraminiferal crusts, recent precipitates of reef surfaces) was determined by electron microprobe analysis. Carboncoated polished thin sections of LR-White-embedded samples were used. The analyses were performed at $15 \mathrm{kV}$ and $12 \mathrm{nA}$ on a JEOL JXA 8900 RL electron microprobe at the Institute of Geochemistry, Göttingen. Fiftyfour spot measurements and five line scans (166 spot measurements) were performed to differentiate mineral phases. $\mathrm{Ca}, \mathrm{Mg}$, and $\mathrm{Si}$ were analyzed for 16 seconds, whereas $\mathrm{Sr}$ was analyzed for 30 seconds. Note that data in wt $\%$ (oxides) refer to whole-rock composition, whereas mole $\%\left(\mathrm{CaCO}_{3}\right.$, $\mathrm{MgCO}_{3}$ ) and ppm (Sr) refer to the carbonate phase. The detection limit (limit of quantification) is given by $I_{d l}=t_{z}(P ; f) \times \sigma_{B G}$, where $t_{z}=$ level of significance, $P=$ confidence level (95\%), $f=$ degrees of freedom, and $\sigma_{B G}=$ standard deviation of the background intensity. Typical detection limits are 0.06 wt $\%$ for $\mathrm{CaO}, 0.05$ wt $\%$ for $\mathrm{MgO}, 0.08$ wt $\%$ for $\mathrm{SrO}$, and $0.42 \mathrm{wt} \%$ for $\mathrm{SiO}_{2}$. The statistical error was calculated by $\Delta \mathrm{n} \%=$ $(\mathrm{V} n / \mathrm{n}) \times 100$, where $\mathrm{n}$ denotes the absolute counts. Typical statistical errors are 0.17 wt $\%$ for $\mathrm{CaO}, 0.03$ wt $\%$ for $\mathrm{MgO}, 0.02$ wt $\%$ for $\mathrm{SrO}$, and $0.01 \mathrm{wt} \%$ for $\mathrm{SiO}_{2}$. The locations of measurement points were controlled by epifluorescence microscopy. The craters in the samples caused by the electron beam were $10-15 \mu \mathrm{m}$ in size.

Hydrochemical calculations of saturation indices and modeling simulations of seasonal lake cycle and EPS degradation were carried out using the computer program PHREEQC (Parkhurst 1995). For mass-balance calculations, the volumes of lake water layers were determined by area measurements (Metamorph ${ }^{\circledR}$ Imaging software) of the Satonda crater lake bathymetric map published in Kempe and Kazmierczak (1993). Reef surface biofilm area has been determined by adding a vertical cylindrical plane (corresponding to $0.3-0.9 \mathrm{~m}$ depth) to the horizontal area of flooded reef tops, followed by multiplication by a roughness factor. The latter factor has been calculated from surface morphology of reef-top thin sections. Biofilm volume of reef top section was determined from biofilm thickness (140 measurements in 7 thin sections) and reef surface area as described above. The calcified proportion of biofilms was ascertained in 7 thin sections from total biofilm area and calcified area in thin sections using the Metamorph ${ }^{\circledR}$ Imaging software. 


\section{RESULTS}

\section{Facies Succession of Subfossil Reef Carbonates}

No complete, continuous section through the red-algal-microbialite reefs is available. Maximum total thickness from the volcanic substrate rock to the living surface is estimated to be approximately $1 \mathrm{~m}$ (Kempe and Kazmierczak 1993). A succession of three major facies types is reconstructed on the basis of blocks broken from the reefs. The contact with basement boulders was observed only at the subaerially exposed reef tops during the dry season in October 1993.

In principle, the base of succession is composed of a serpulid tube framework ("serpulite"). The major part of the reef is formed by a microbialite encasing green-algal molds. This facies type is the dominant microbialite portion of the reefs and was studied in greater detail. The youngest carbonate veneers are formed by red-algal crusts with a thin living layer of red algae on top, covered by living biofilms, green algae, and sponges. Detailed descriptions of the three facies follow.

"Serpulite."-This facies type was observed directly covering basalt boulders and is also known from pit sections between the reef heads (Kempe and Kazmierczak 1993; Kempe et al. 1996). The highly porous framework consists of serpulid tubes $(250 \mu \mathrm{m}-1.8 \mathrm{~mm}$ inner diameter), which are encrusted by smaller coiled Spirorbis tubes. Open voids are partly filled with volcanic detritus (feldspar, augite), foraminifera (mainly Miliolidae) and small gastropods. Fibrous aragonite cement of varying thickness (10 to $250 \mu \mathrm{m}$ ) locally occurs inside the tubes, predominantly in the smaller ones. A spatial interfingering with the overlying "green-algal microbialite," as indicated by fibrous microstromatolitic crusts upon serpulite tubes and by micropeloidal void sediment, was observed in one thin section. The depth range of the serpulite facies is unknown. Marine bivalves (Pteroidea) with Spirorbis tubes from soft sediments between the reefs at $15 \mathrm{~m}$ depth probably correspond to the serpulite. The serpulite facies has been considered by Kempe et al. (1996) as a marine interstage, possibly caused by the percolation of seawater through the crater wall during a past high sea-level stage.

"Green-Algal Microbialite."-This facies type corresponds to the "stromatolitic-siphonocladalean" and the "peloidal" zone of Kempe and Kazmierczak (1993), because these two zones grade into each other vertically and laterally. The "green-algal microbialite" overlies the previously described, older "serpulite" without sharp boundary and is at least $20 \mathrm{~cm}$ thick. Kempe and Kazmierczak (1993) report a maximum thickness of 60 $80 \mathrm{~cm}$. "Stromatolitic-siphonocladalean" samples (Fig. 2A-E) have been collected only from the reef tops, whereas samples of "micropeloidal" limestone (Fig. 3A-C) are present from the reef top down to $15 \mathrm{~m}$ depth.

The basic framework of this facies is formed by tufts and bushes of erect, locally entangled tubes of siphonocladalean green algae (Figs. 2A, $3 \mathrm{~A}$ ). These are preserved as molds 100 to $200 \mu \mathrm{m}$ in diameter, either open or partly to completely filled by isopachous to botryoidal fibrous aragonite. The cell walls and boundaries are evident at the basal contacts of the cements. In addition, some tufts show constrictions at cell boundaries. Dichotomous branching is observed rarely to abundantly in the different tufts. The outer surface of the green algal filament molds is given by fibrous microstromatolitic crusts, cemented void sediment, or (in a few samples) by microcrystalline to cryptocrystalline veneers that are up to $10 \mu \mathrm{m}$ thick.

The characteristic microstromatolitic crusts that veneer the green algal molds are 0.5 to $1.3 \mathrm{~mm}$ thick and are composed of up to 20 fibrous layers, each 20 to $60 \mu \mathrm{m}$ thick (Fig. 2A-D). Each layer starts with a cryptocrystalline to amorphous base (often less than $5 \mu \mathrm{m}$ thick) upon which fibrous aragonite nucleated (Fig. 2B-D). The fibrous parts are finally terminated by a smooth, undulating surface. The next layer starts again with a cryptocrystalline to amorphous base. One to three of the cryptocrystalline to amorphous layers reach up to $60 \mu \mathrm{m}$ thickness and can be traced thoughout the crusts of a thin section.
Electron microprobe analyses (Fig. 4) revealed that fibrous crust parts consist of aragonite with 98.4 mole $\% \mathrm{CaCO}_{3}$ and $8400 \mathrm{ppm} \mathrm{Sr}$ (i.e., 55 wt $\% \mathrm{CaO}, 1$ wt $\% \mathrm{SrO}$ ), whereas cryptocrystalline to amorphous parts are composed of an undetermined phase with an $\sim 1: 1$ molar ratio of $\mathrm{Mg}$ and $\mathrm{Si}$ (36-45 wt \% $\mathrm{SiO}_{2}, 15-29$ wt \% MgO). No high-Mg calcite has been detected within the microstromatolitic crusts.

Numerous organic remains are enclosed within the microstromatolitic crusts. Most striking are abundant, straight to curved filaments $1 \mu \mathrm{m}$ in diameter and up to more than $200 \mu \mathrm{m}$ in length, which appear dark in transmitted light (Fig. 2B-D). They cross-cut the fibrous aragonite fabric and show occasional, irregular branching. Far less abundant are brownish, organic-walled spheres $5 \mu \mathrm{m}$ in diameter that occur isolated or in groups of three to more than ten (Fig. 2E). Although enclosed in the aragonite, there is no interference with the fibrous crystallite fabric. Aggregates of brownish, coccoid remains that might represent former coccoid cyanobacteria have been observed in only a few cases and are restricted to the contact between the fibrous aragonite layers and the succeeding amorphous $\mathrm{Mg}-\mathrm{Si}$ layer (Fig. 2D). They occur in depressions of the fibrous layer below, but the relative time sequence of the different layers and the coccoid microfossils remains unclear. In any case, the thin, amorphous $\mathrm{Mg}-\mathrm{Si}$ layers show a sharp contact with the fibrous aragonite layers below. This contact commonly shows scalloped morphologies, which are considered to represent dissolution pits (Fig. 2B). Additional organic inclusions that occur within the aragonite include a few, single, boat-shaped diatoms less than $20 \mu \mathrm{m}$ long (Fig. 2B). The remaining voids between the green-algal-stromatolitic framework are partially to completely filled with micropeloidal sediment with abundant pellets, skeletal detritus, and siliciclastic detritus, cemented by an amorphous matrix or fibrous aragonite (Figs. 2A, 3A, 4).

Electron microprobe analyses (two line sections: 53 point measurements) reveal that micropeloids and fibrous cements of the voids consist of aragonite. Cryptocrystalline to amorphous matrix parts are composed of an undetermined $\mathrm{Mg}-\mathrm{Si}$ phase identical to the one mentioned above. In contrast, pellets show a high-Mg calcite composition with $\sim 23$ mole $\%$ $\mathrm{MgCO}_{3}$

Many microbialite samples taken from the surface of the seasonally exposed reef tops show poorly developed microstromatolitic crusts veneering green algal filament casts (Fig. 3A). Instead, a micropeloidal framework composed of irregular, fibrous aragonite aggregates is developed. Aragonite-cemented casts of siphonocladalean algae without stromatolitic encrustation occur in reef-top samples, whereas green-algal molds are absent at greater depths $(15 \mathrm{~m})$. Some reef-top samples show aragonite-cemented accumulations of diatoms between the green-algal molds (Fig. 5A). Electron microprobe analyses indicate that the commonly brownish-colored cell walls of the green algae are permineralized by a $\mathrm{Mg}-\mathrm{Si}$ phase, though the microprobe sampling area covered the 2 - $\mu$ m-thick cell walls and adjacent aragonite (Fig. 5B, C). On the basis of this observation, a $\mathrm{Mg}-\mathrm{Si}$ permineralization of cell walls is possibly an explanation for the preservation of coccoid cell remains (Fig. 2B, D-E) in subfossil microbialites of Lake Satonda.

Aggregates of aragonite micropeloids are commonly $25-100 \mu \mathrm{m}$ in size and show dark microcrystalline centers with radiating, light, aragonite fibers (Fig. 3A). Locally, a partial silicification of the micropeloidal carbonate (Fig. 3B, C; below red-algal crust) preserved colonies of pleurocapsalean cyanobacteria between the aragonite microclots. It is noteworthy that the aragonite is not present as a permineralization of cyanobacterial colony sheaths but occurs in the form of separate microclots (Fig. 3C) as observed in recent reef-top biofilms.

At present-day reef surfaces, the whole fabric is affected by younger dissolution processes, which have resulted in enlargement of primary voids and truncation of fabrics. The younger fibrous aragonite cements discontinuously line the voids and smooth the microrelief. With regard to their fabric and chemical composition, these younger cements are identical to the microstromatolites. 


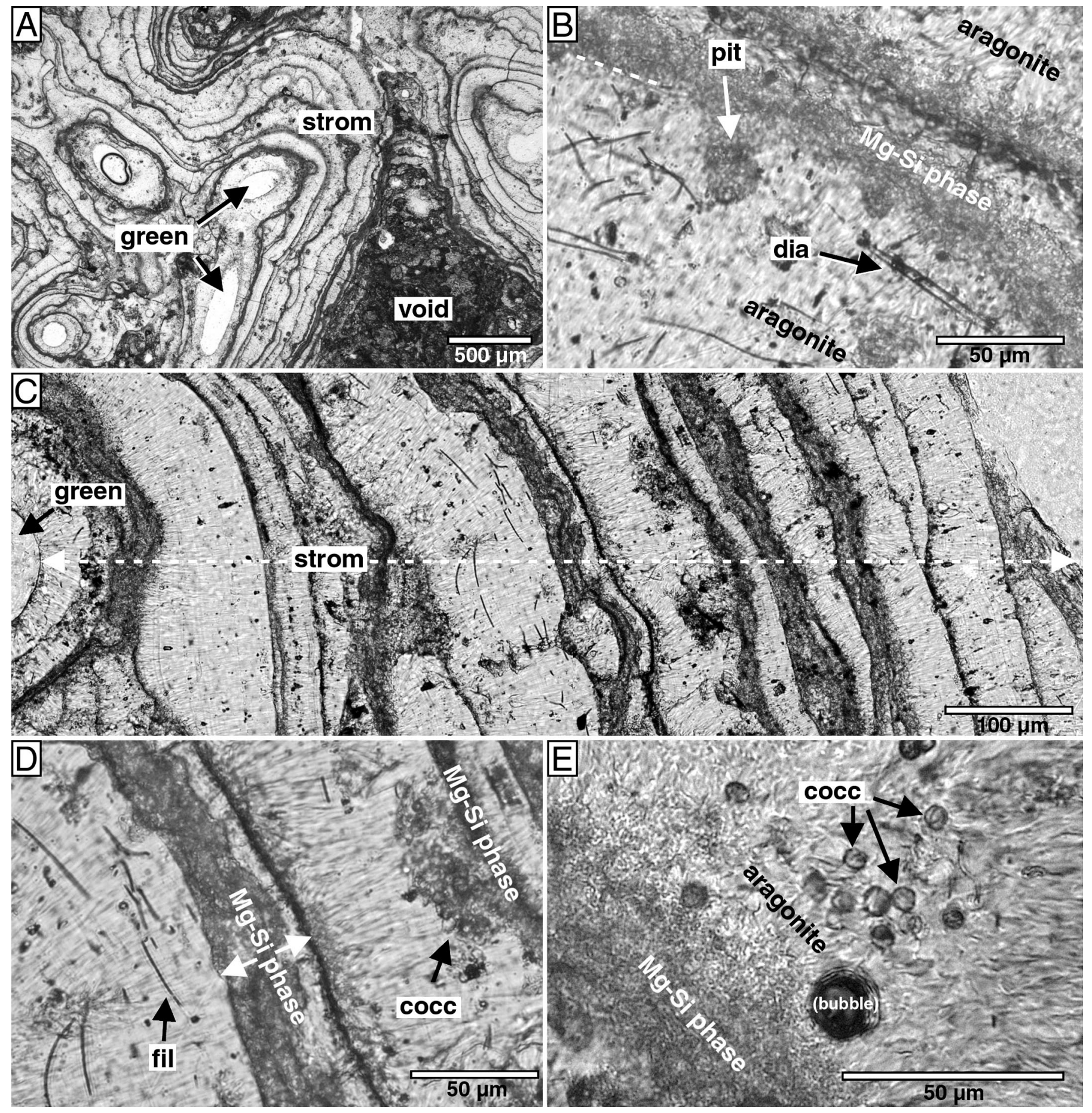

FIG. 2.-Subfossil reef carbonates. A) Main part of the reef composed of microstromatolitic crusts (strom) encasing former filaments of siphonocladalean green algae (green) similar to the recent Cladophoropsis. Framework void (void) is partly filled by micropeloidal sediment, fecal pellets, and skeletal and siliciclatic detritus within an amorphous or microcrystalline matrix. Dry shore, reef \#1. Transmitted light. Sample Sat 93/74 (1813). B) High-magnification view of microstromatolite laminae alternation. Note the sharp basal contact (dashed line) of the $\mathrm{Mg}$-Si layer. The associated pits (pit) are cutting into the fibrous aragonite, probably indicating dissolution prior to or concurrent with the formation of the Mg-Si-phase. Note elongated diatom remains (dia) within the top of the fibrous aragonite layer. Dry shore, reef \#1. Transmitted light. Sample Sat 93/74 (1813). C) Microstromatolitic crust (strom) composed of fibrous aragonite layers (light) and thin laminae of an amorphous to microcrystalline Mg-Si phase (dark). To the left, the basal contact to a former green-algal filament (green) is visible. Dry shore, reef \#1. Transmitted light. Sample Sat 93/74 (1813). D) Detail of part $\mathrm{C}$ showing filamentous structures (fil) of supposed fungal origin cross-cutting the fibrous aragonite fabric of the microstromatolites. The filamentous structures are interpreted to be of endolithic origin, therefore should be destructive rather than involved in constructive processes of crust formation. Note remains of coccoid microorganisms (cocc) within the top of one of the aragonite layers. Such coccoid remains are rare and might result form coccoid cyanobacteria, although their role in crust formation remains interpretive. Dry shore, reef \#1. Transmitted light. Sample Sat 93/74 (1813). E) Remains of coccoid microorganisms (cocc) within the basal part of a fibrous aragonite layer. These spheres may result from coccoid green algae, cyanobacteria, or spores. Because of the scattered arrangement of the remains, an origin from benthic coccoid cyanobacteria is considered unlikely. The large "sphere" is an artificial bubble in the section. Dry shore, reef \#1. Transmitted light. Sample Sat $93 / 74$ (1813). 

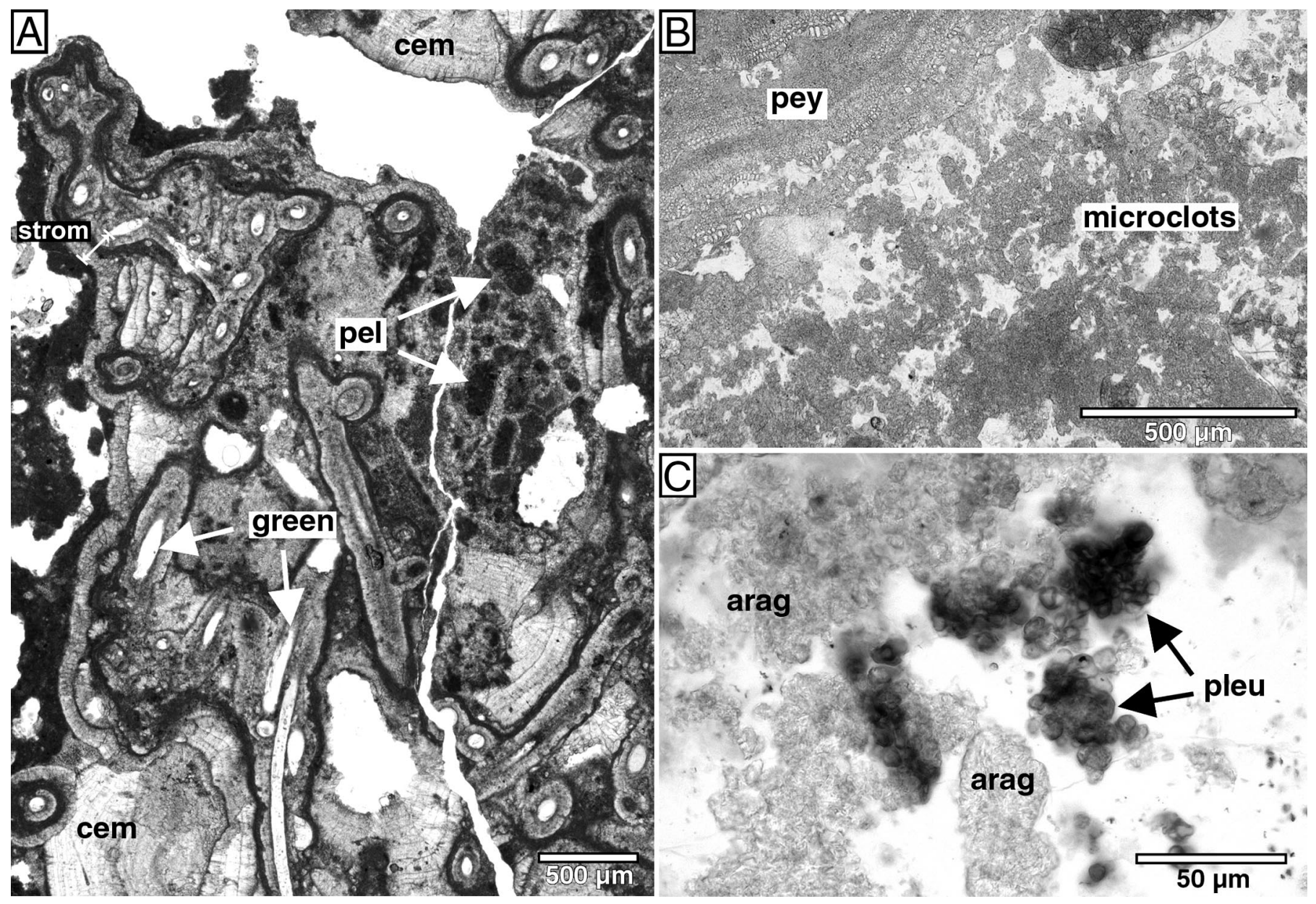

FIg. 3.-Subfossil reef carbonates. A) Green-algal-microstromatolite framestone showing erect green-algal filament tubes (green) encrusted by microstromatolites (strom), and voids filled with aragonitic micropeloids (pel) within a $\mathrm{Mg}-\mathrm{Si}$ matrix. Note fan-shaped aragonite cements (cem) that formed within voids. $0.3 \mathrm{~m}$ depth, reef \#1. Transmitted light. Sample Sat 96/14. B) Micropeloidal aragonite layer (microclots), containing silicified pleurocapsalean cyanobacteria, overlain by a red-algal crust (pey). $7 \mathrm{~m}$ depth, reef \#1. Transmitted light. Sample Sat 93/6. C) Silicified pleurocapsalean colonies (pleu) between aragonite microclots (arag) of the micropeloidal layer shown in part B. 7 m depth, reef \#1. Transmitted light. Sample Sat 93/6.

Conspicuous structures associated with microstromatolitic crusts and micropeloidal parts in semicryptic voids of Satonda reefs are semiglobular structures (Fig. 6A, B), which have been compared to the Paleozoic microproblematicum Wetheredella (Kazmierczak and Kempe 1992). The semicircular to halfmoon-shaped sections are 90-190 $\mu \mathrm{m}$ in height and 120-290 $\mu \mathrm{m}$ in width. One or two aragonite arrays, which originate at the basal substrate, form these structures. The outer limit is sharply defined by a dark line or a less than $5 \mu \mathrm{m}$ thick organic wall (Fig. 6B).

"Red-Algal-Foraminiferal Crusts."-Red-algal-foraminiferal crusts form the youngest parts of the Satonda reefs. They veneer older reef parts from the seasonal lowstand level down to below the chemocline at 22-24 m depth and correspond to the "cyanobacterial-red-algal zone" of Kempe and Kazmierczak (1993). The highly porous, cornflake-like framework is composed of foliaceous thalli of the squamariacean red alga Peyssonnelia with irregular to lenticular, millimeter-size voids in between (Fig. 6C). The voids are partially or completely filled by aragonite-cemented fecal pellets, miliolid foraminifera, rare gastropods, and patches of micropeloids. Lower sides of Peyssonnelia thalli are characterized by hypobasal aragonite botryoids that are marginally micritized (Fig. 6C; Kempe and Kazmierczak 1993). These highly porous crusts are commonly $5 \mathrm{~cm}$, and locally $15-25$ cm, thick at depths below $5 \mathrm{~m}$ (Kempe and Kazmierczak 1993). The thickness of these crusts decreases downwards to $3-4 \mathrm{~cm}$ close to the chemocline. In shallow reef parts $(0.3 \mathrm{~m}$ below seasonal lowstand $)$ red-algal crusts are missing. Electron microprobe analyses (Appendix 3, see Acknowledgments) indicate an aragonite mineralogy for Peyssonnelia thalli and fibrous cements, high-Mg calcite for fecal pellets, micrite fillings within Peyssonnelia thalli, and nubecullinid foraminifera, and amorphous $\mathrm{Mg}-\mathrm{Si}$ for matrix parts.

A final, dense, smooth to dendroid crust composed of the squamariacean Peyssonnelia, the coralline red alga Lithoporella, and nubecullariid foraminifera form overgrowths on the cornflake-like red-algal crusts and older microbialites (Fig. 3B). The Peyssonnelia thalli commonly show a lightdark lamination due to alternating cell sizes. Layers of small cells thereby appear "micritic" at first glance but are composed of aragonitic microfibers. Mineralized coccoid cyanobacteria have been observed in the horizontal crevices between the thalli. However, all of these coccoid cyanobacteria were preserved by silification (amorphous $\mathrm{Mg}-\mathrm{Si}$ phase) and no $\mathrm{CaCO}_{3}$ permineralization was found. Electron microprobe analyses performed on this final dense red-algal crust confirm the previously described composition of skeletons (Fig. 7). Aragonitic Peyssonnelia thalli alternate with high-Mg calcitic Lithoporella thalli and nubecullinid foraminiferal tests. The amorphous $\mathrm{Mg}-\mathrm{Si}$ phase is restricted to horizontal crevices near the reef surface and a few small pore spaces, but it also occurs as a partial silification of Mg-calcitic Lithoporella thalli (Fig. 7).

The uppermost living thalli of the final dense red-algal crust represent the presently growing part of the reefs. In shallow water this final crust 

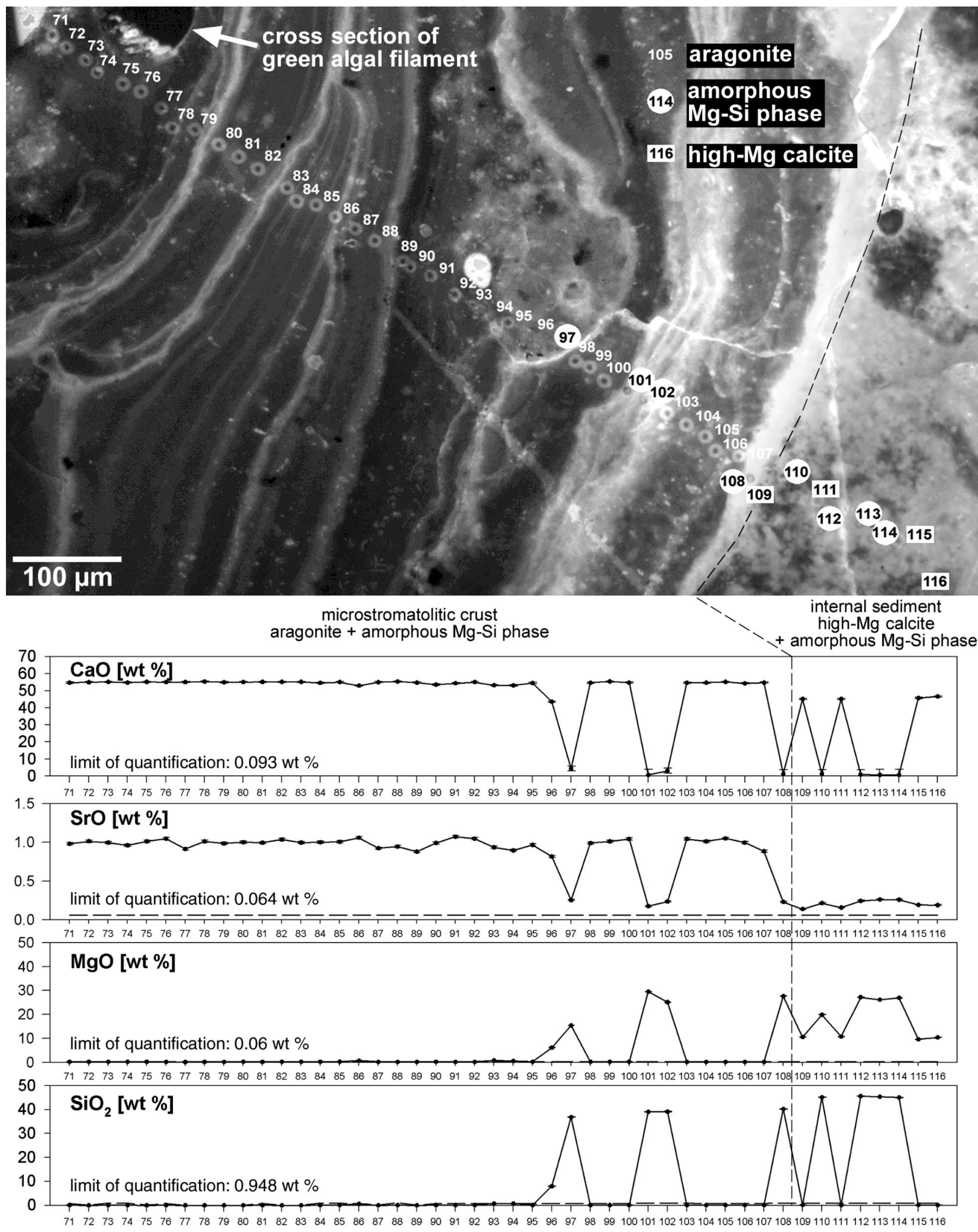

FIG. 4.-Electron microprobe traverse of a microstromatolitic crust of the subfossil reef core. Sample Sat 93/74 (1813). Dark-appearing layers are composed of aragonite, whereas thin, light layers are formed by an unidentified $\mathrm{Mg}-\mathrm{Si}$ phase. High-Mg calcite is restricted to internal sediment of pockets between the microstromatolites. 

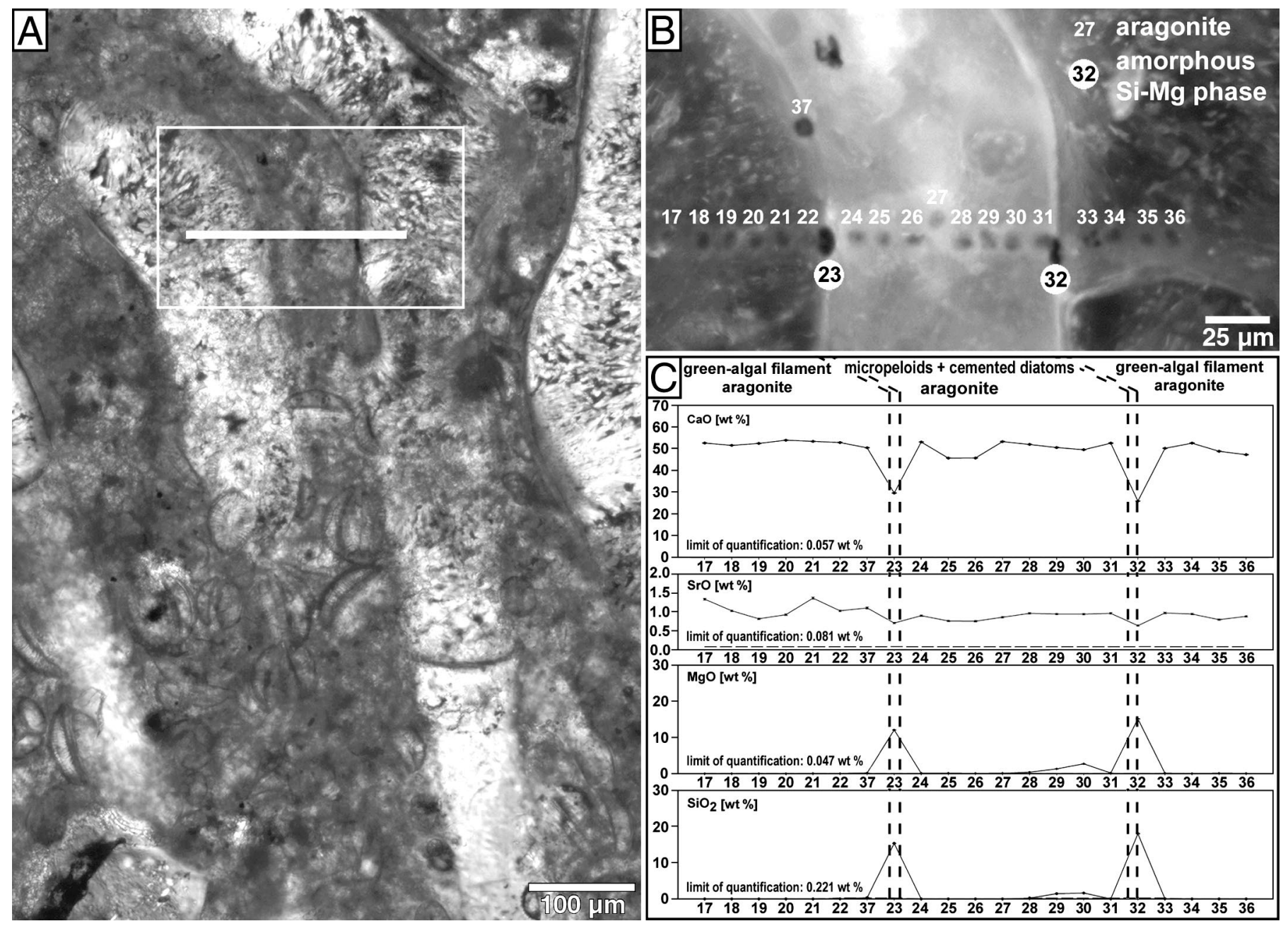

FIG. 5.-Electron microprobe section of a subfossil green-algal-microbialite sampled at a seasonally exposed reef top. Sample Sat $96 / 18,0.5 \mathrm{~m}$ depth, reef \#1. A) Overview of the green-algal-microbialite section. Spaces between green-algal moulds are infilled by halfmoon-shaped diatoms encased in aragonite cement. White line indicates transect in part B. B, C) Transect across marginal parts of green-algal molds, their walls, and the carbonate between two filaments. Measurement points 23 and 32 are interpreted as mixed signals of an amorphous $\mathrm{Mg}-\mathrm{Si}$ phase and the surrounding aragonite (note $\mathrm{Sr}$ contents).

locally veneers directly the "green-algal microbialites," separated by a corrosion plane. Crusts dominated by nubecullariid foraminifera protrude even into near-surface cavities of the subfossil cornflake-like red-algal framework and corroded green-algal microbialites.

\section{Reef-Surface-Living Biota and Biofilms of the Dry Season}

Samples from the living reef surface were obtained from the water line down to below the chemocline at $22 \mathrm{~m}$ depth (Appendix 2). Owing to gaps in the sampling profile, boundaries or transitions cannot be assigned to defined depths.

Cyanobacterial and bacterial biofilms on living red algae are generally less than $10 \mu \mathrm{m}$ thin and grow preferentially within depressions or subsurface voids of the red-algal crusts. It is important to note that all investigated biofilms generally comprise a large portion of non-phototrophic microorganisms, above all filamentous bacteria. In addition, fungal hyphae and numerous coccoid and rod-shaped bacteria are present, especially at decaying sponge tissues. Three zones between the lake-level lowstand and the chemocline and one below the chemocline are defined.

Peyssonnelia-Lithoporella Zone.-Reef surfaces between the seasonal lowstand and approximately $7 \mathrm{~m}$ depth are characterized by living Peyssonnelia-Lithoporella crusts and a dense meadow of attached siphonoclad- alean green algae. The squamariacean Peyssonnelia dominates in shallow water, whereas the corallinacean Lithoporella is increasingly abundant with depth. However, living thalli of both taxa are present thoughout this zone (Fig. 8A, B). Insect larval tubes, which occur regularly at shallow depths, are veneered by the red-algal thalli, also. Reef-surface biofilms of the redalgal crusts are discontinuously developed, usually less than $10 \mu \mathrm{m}$ thick, and comprise rod-shaped and filamentous, non-phototrophic bacteria (Fig. $8 \mathrm{E}, \mathrm{F})$. Heterotrophic bacteria, which digest cell walls of dead green algal filaments, have been detected by TEM sections (Arp et al. 1996). In addition, fungal hyphae, which penetrate filaments of cyanobacteria, are also present (Arp et al. 1996). Hadromerid sponges (Laxosuberites sp.) locally veneer the living or dead red-algal thalli. Their contact with the calcareous red-algal substrate is always mediated by a thin biofilm of non-phototrophic bacteria.

Phototrophic microorganisms, such as pennate diatoms, coccoid algae (Fig. 8E, F; "Dermocarpella"), and the cyanobacteria Pleurocapsa and Phormidium spp., occur only scattered on the red-algal surfaces. Only in depressions of the surface and at the surface of green algal filaments are cyanobacteria and diatoms more common, always associated with non-phototrophic bacteria. In contrast, several samples show abundant pleurocapsalean cyanobacteria in subsurface voids between the living crustose red- 

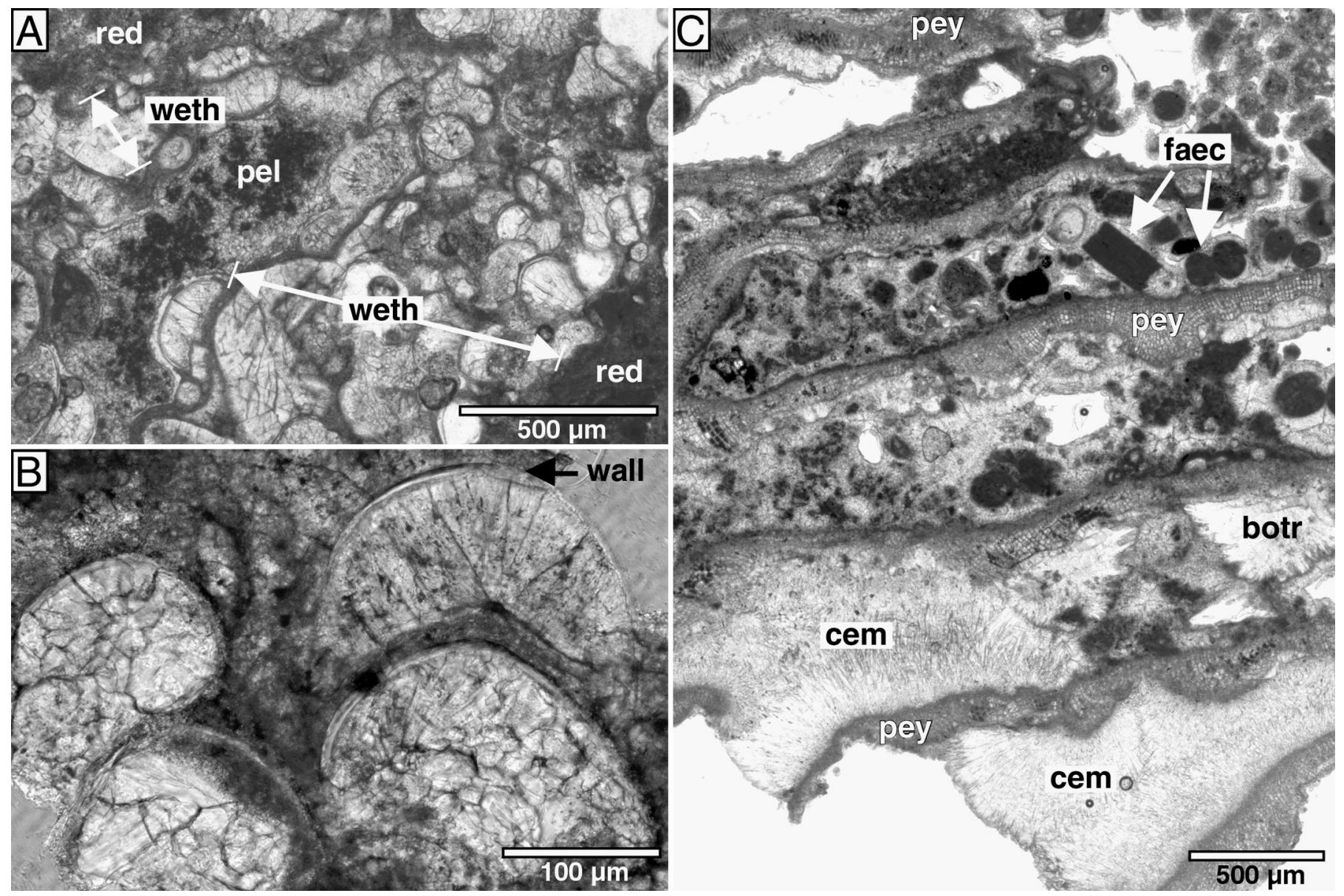

FIG. 6.-Subfossil Wetheredella-like structures and reef carbonates. A) Subfossil cystous structures (weth) forming a crust within a cavity of the red-algal reef framework (red). These cystous structures, superficially reminiscent of the Paleozoic microproblematicum Wetheredella, are considered herein to be fossilized resting bodies of sponges. The remaining pore space is filled by aragonite-cemented micropeloids (pel). Dry shore, reef \#1 Transmitted light. Sample Sat 93/44. B) Close-up view of Wetheredellalike structures showing radial-fibrous aragonite and a distinct, defined wall (wall). Dry shore, reef \#1.Transmitted light. Sample Sat 93/44. C) Foliaceous thalli of the calcified squamariacean red alga Peyssonnelia (pey) form a "cornflake-like" reef framework in the younger reef. Lower sides of the thalli occasionally show hypobasal aragonite botryoids (botr). The remaining irregular to lenticular voids are partly filled by aragonite-cemented micropeloids (pel), fecal pellets (faec), and fibrous aragonite cements (cem). 24-25 m depth, reef \#10/11. Plane-polarized light. Sample Sat 93/28.

algal thalli (Fig. 8B). In addition, endolithic cyanobacteria of the Hyella group, which bore in living and dead Peyssonnelia thalli, have been observed in one sample from $0.5 \mathrm{~m}$ depth (Fig. 8C, D). Pleurocapsa colonies are abundant only in crevices between the red-algal thalli, but they remain soft and unmineralized (Fig. 8B). Green-algal holdfasts are located in the depressions or are already overgrown by the calcareous red-algal thalli. Such enclosed green-algal filaments form the only places where non-skeletal aragonite precipitation was observed in one single sample (Fig. 8A). Fibrous aragonite formed inside of lysed green-algal cells, whereas aragonite precipitates were observed neither in adjacent biofilms of the reef surface nor in cryptic biofilms in their vicinity. Crevices and voids of the red-algal framework are commonly rich in flocculent organic material (decaying sponge tissues, organic detritus) and cyanobacteria, and reveal an extensive population of coccoid bacteria, which apparently decompose the organics. No carbonate precipitates were observed in association with the bacterial decomposition of organic matter. Figure 9 is a schematic drawing that summarizes the observations on samples from the reef-surface crusts of the Peyssonnelia-Lithoporella zone.

Pleurocapsa-"Dermocarpella"' Zone.-Deeper-water samples (14-18 $\mathrm{m}$ depth) have surfaces that are composed largely of dead Peyssonnelia thalli that are overgrown by almost continuous Pleurocapsa-"Dermocarpella" biofilms. Erect and prostrate Phormidium spp. (0.75 $\mu \mathrm{m}$ and $2 \mu \mathrm{m}$ diameter) occur in varying abundance also. Living Lithoporella monolayers are still present, but less abundant and discontinuously distributed within the biofilm. Siphonocladalean green algae have not been found at that depth, but hadromerid sponges occur at least at up to $18 \mathrm{~m}$ depth.

Non-Phototrophic Biofilm Zone.-On the basis of one sample taken at 24-25 m depth, reef surfaces below the chemocline are composed of dead Peyssonnelia-Lithoporella crusts that are veneered by 10-20 $\mu \mathrm{m}$ thick, detritus-rich, soft biofilms of non-phototrophic bacteria. The detritus consists of organic particles, siliciclastic grains $(<10 \mu \mathrm{m})$ and few Mn hydroxide particles. Microorganisms are dominated by filaments more than $60 \mu \mathrm{m}$ long and 0.4-0.5 $\mu \mathrm{m}$ thick, of supposed bacterial origin. No branching has been observed in these filaments. In addition, numerous coccoid $(0.65 \mu \mathrm{m})$ and rod-shaped $(0.25-0.5 \mu \mathrm{m}$ diameter; $1 \mu \mathrm{m}$ long) bacteria are present in the biofilm. Rare spirillae $(0.5 \mu \mathrm{m} ; 3.25 \mu \mathrm{m}$ long $)$ and coccoid phototrophs (?cyanobacteria, $2.3 \mu \mathrm{m}$ in diameter) occur in small groups of eight cells and less.

\section{Reef-Surface-Living Biota and Biofilms of the Wet Season}

The zonation of the reef-surface communities in June 1996 differed from that of October 1993. The lake level in June 1996, a few weeks after the end of the rainy season, was still approximately $0.4-0.5 \mathrm{~m}$ higher than 


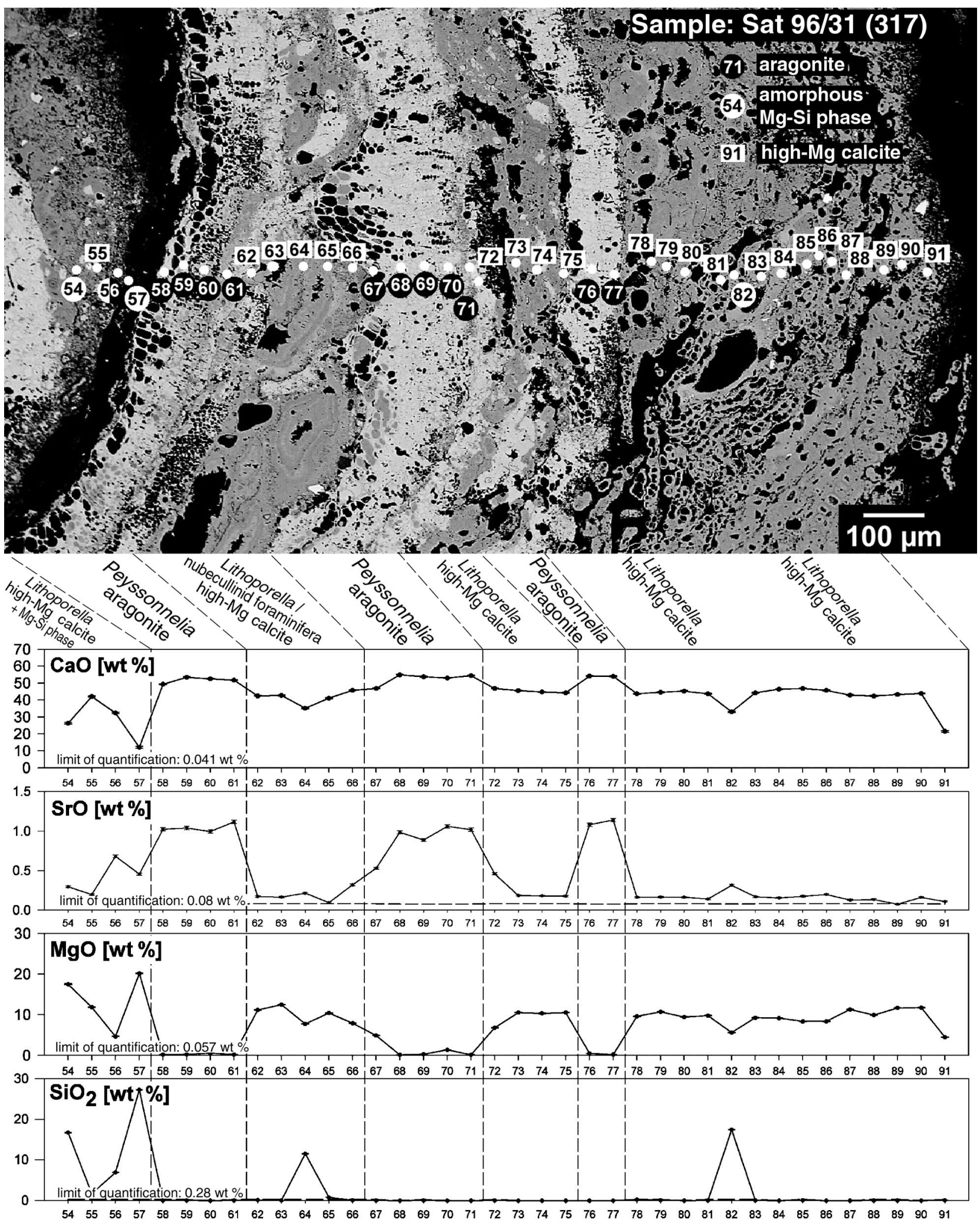

FIG. 7.-Electron microprobe traverse of a red-algal-foraminiferal crust of the reef surface at $17 \mathrm{~m}$ depth (reef \#1). Aragonitic Peyssonnelia thalli alternate with Mgcalcitic Lithoporella thalli. An amorphous Mg-Si phase occurs in voids and crevices but also partially replaces Mg-calcitic Lithoporella skeletons. 


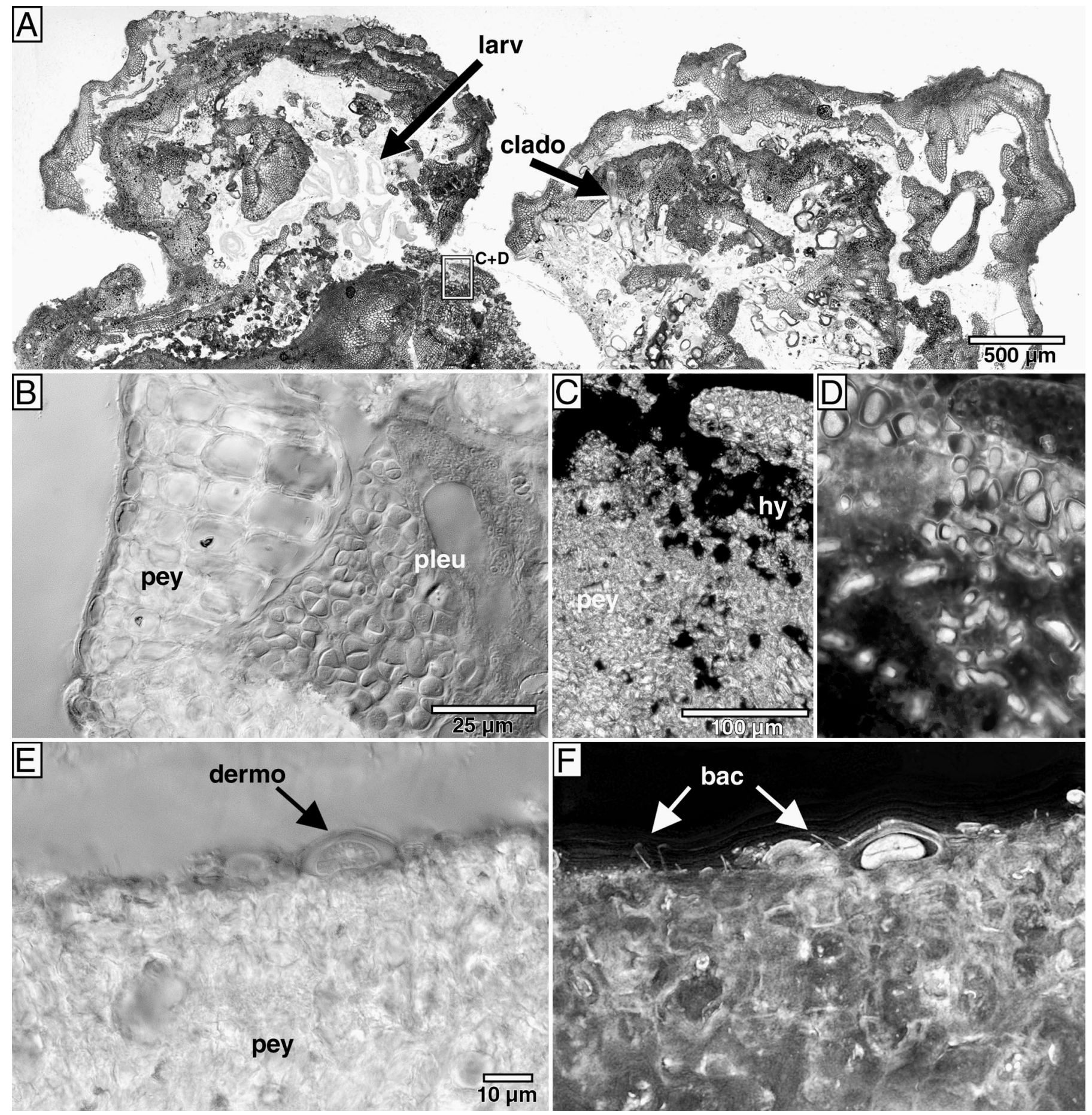

FIg. 8.-Reef-surface biota and biofilms of the October 1993 dry season. A) Overview of living Lithoporella-Peyssonnelia crusts of the reef surface. Note arthropod larva in void of the red-algal framework (arrow). $0.5 \mathrm{~m}$ depth, reef \#1. Transmitted light. Sample Sat 93/4. B) Uncalcified Pleurocapsa (pleu) in subsurface void below living Peyssonnelia (pey) of the reef surface. $0.5 \mathrm{~m}$ depth, reef \#1. Nomarski optics. Sample Sat 93/4. C) Borings of endolithic cyanobacteria of the Hyella group (hy) within dead, calcified Peyssonnelia thalli (pey). $0.5 \mathrm{~m}$ depth, reef \#1. Crossed nicols. Sample Sat 93/4. D) Same view as in part C to show fluorescent cells of the endolithic Hyella. Epifluorescence image (ex 450-490 nm, em 520-575 nm), contrast enhanced by green fluorescing calcein). For scale see part C. E) Non-calcified biofilm comprising the hemispherical, unicellular alga "Dermocarpella" (derm) on dead red-algal reef surface (pey). $18 \mathrm{~m}$ depth, reef \#1. Nomarski optics. F) Deconvolved epifluorescence micrograph (ex 450-490 nm, em 520-575 nm) of the same view shown in part E. Note rod-shaped and filamentous bacteria (bac) of the biofilm. For scale see part E. 


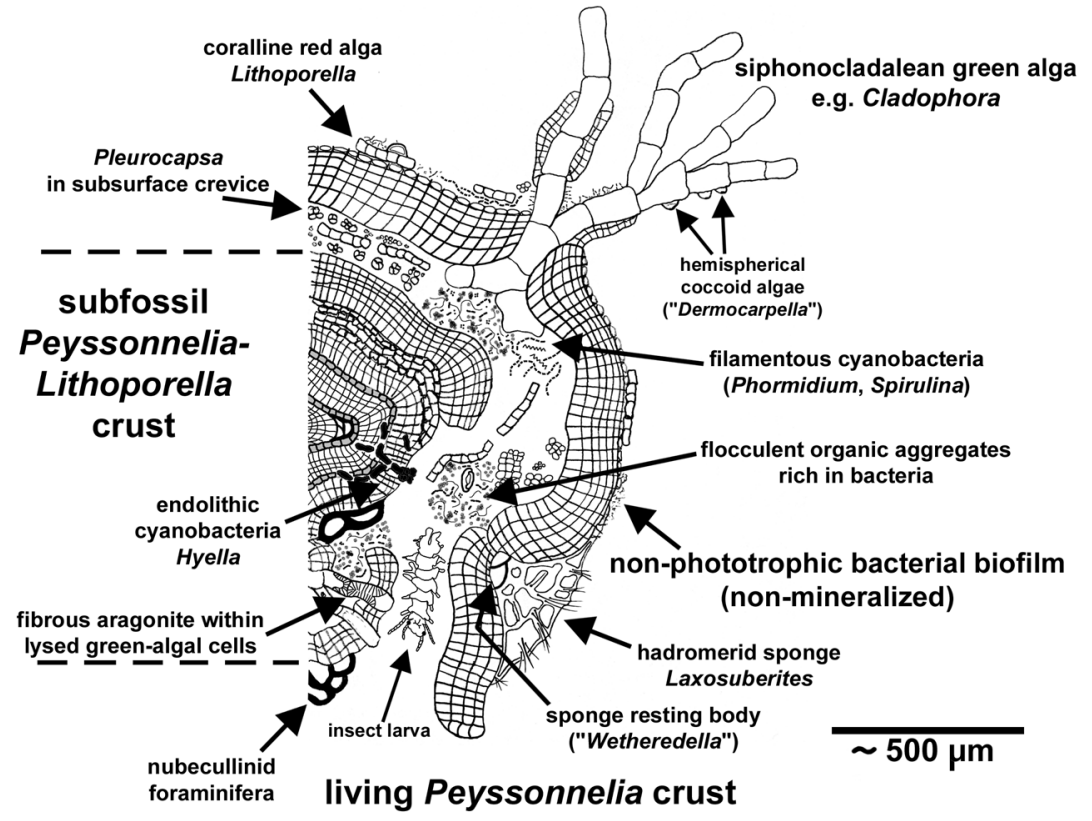

FIG. 9.-Schematic diagram of the reef-surface crusts of the Peyssonnelia-Lithoporella zone (015 m depth), dry season, October 1993 . Note that cyanobacteria are most common in crevices between the calcareous red algal thalli, and that non-skeletal carbonate precipitation is observed only in lysed green-algal cells ( $0.5 \mathrm{~m}$ depth). during the sampling campaign in October 1993, although about $0.5 \mathrm{~m}$ of lake water had already evaporated (as indicated by highstand marks on trees and volcanic boulders). Two distinct changes in reef-surface biofilm community composition and macroalgal vegetation (see below) at 0.4 and $0.6 \mathrm{~m}$ depth may reflect lowstands of the previous years. Samples from below the chemocline are not available for the 1996 sampling campaign.

Phormidium-Calothrix-Pleurocapsa Zone.-Wet-season samples (0.3$0.6 \mathrm{~m}$ ) of the seasonally exposed reef tops show Phormidium-CalothrixPleurocapsa biofilms (Fig. 10A, B). Below a boundary at $0.4 \mathrm{~m}$ depth hemispherical tufts of the green alga Cladophoropsis 1-2 cm in size are scattered throughout the surface. The cyanobacterial biofilm corrodes and discontinuously cuts the subfossil "green-algal microbialite" that serves as substrate rock. Corrosion is indicated by a cutting of subfossil fabrics, extensive microborings, and the "excavation" of subfossil, aragonite-cemented green-algal molds. Figure 11 summarizes the composition and structure of the biofilms of the Phormidium-Calothrix-Pleurocapsa zone.

The cyanobacterial biofilms are 300-700 $\mu \mathrm{m}$ thick and display a distinct internal zonation (Figs. 10A, 11). The subfossil green-algal microbialite is intensely bored by endolithic cyanobacteria of the Hyella group, which is characterized by cell colonies morphologically identical to the closely related but non-endolithic Pleurocapsa group (Geitler 1932; Komárek and Anagnostidis 1986). True Pleurocapsa colonies occur preferentially near the base at the contact with the substrate rock (Fig. 10A) and are far less abundant in higher biofilm parts. Most parts of the biofilm are formed by a dense plexus of thin Phormidium filaments of $0.8 \mu \mathrm{m}$ trichome diameter. A second Phormidium morphotype of $2 \mu \mathrm{m}$ trichome diameter is less abundant. Numerous erect Calothrix filaments characterize the top near the contact with the liquid phase (Fig. 10A, B). Occasional Spirulina and Oscillatoria filaments have also been observed at the biofilm top. No sponges occur in this seasonally exposed zone, and neither living nor dead red algal thalli were observed.

Millimeter- to centimeter-size voids of the subfossil substrate are commonly veneered by laminated cements that resemble microstromatolitic crusts of the subfossil substrate. Electron microprobe analyses show that they are composed of fibrous aragonite layers and thin amorphous $\mathrm{Mg}-\mathrm{Si}$ layers identical to the microstromatolites. These cements smooth the microrelief. Commonly they are intensely bored by endolithic fungi or cyanobacteria. Thin non-phototrophic biofilms are locally developed upon them (Fig. 10C). In addition, arrays of acicular aragonite and limpid ara- gonite botryoids free of endoliths and biofilms have been observed in the voids, although these findings are rare.

Peyssonnelia-Lithoporella Zone.-Reef surfaces between 0.9 and $15 \mathrm{~m}$ depth are reddish or purple-red spotted owing to living, crustose red-algal thalli, which form a final, dense red algal crust, 1-2 mm thick, on the reefs. The $0.9 \mathrm{~m}$ depth line is characterized by a sudden onset of an extensive green-algal meadow that covers living red-algal crusts. Green algae comprise the genera Cladophora, Chaetophora, and Cladophoropsis. The green-algal meadow extends down to $15-16 \mathrm{~m}$ depth. Abundant yellow sponges colonize the surfaces of the crusts.

Crustose Peyssonnelia thalli form essential parts of the 1-2 mm thick reef surface crust (Fig. 10D), which was present in October 1993. Only the upper 10-15 cell rows, which contain chloroplasts and compartments, are living. The monolayered Lithoporella thalli occur in patches upon and between Peyssonnelia thalli. Living Peyssonnelia thalli dominate in shallow water depths, whereas living Lithoporella thalli reach their maximum at 5 $m$ depth. At the transition into cavities and voids of the reef rock, nubecullinid foraminifera are increasingly abundant in the crusts. However, most of them are dead, and only a few living specimens were observed in sections. Biofilms upon the red-algal crusts are discontinuous, thin, and of patchy distribution. Living red-algal thalli usually exhibit only a 5-10 $\mu \mathrm{m}$ thick biofilm of rod-shaped and filamentous bacteria. Only at holdfasts of green algae do biofilms reach up to $100 \mu \mathrm{m}$ thickness. Cyanobacterial colonies of Pleurocapsa and diatoms occur at these places and within small depressions between the red algae. Surfaces of living red algae show only few, scattered, hemispherical cells of "Dermocarpella" within their thin biofilms (Fig. 10D).

Millimeter- to centimeter-size voids and cryptic cavities below overhanging reef crusts that are in contact with the lake water are characterized by $5-20 \mu \mathrm{m}$ thick microcrystalline veneers (aragonite or Mg-calcite) that smooth the internal microrelief of the voids. Thin non-phototrophic biofilms cover these microcrystalline veneers. At the base of the veneers a conspicuous zone of Mn hydroxide precipitate marks the contact with the subfossil substrate carbonate.

Phormidium-Diatom Zone.-Reef surfaces below the lower limit of the green-algal meadow show only sporadically pigmented red-algal thalli and single, poorly developed green-algal tufts. Instead, the surface is veneered by a yellowish-brown biofilm. The final red-algal crust of the reefs, 1-2 $\mathrm{mm}$ thick, comprises dead thalli of Peyssonnelia and Lithoporella, and dead 

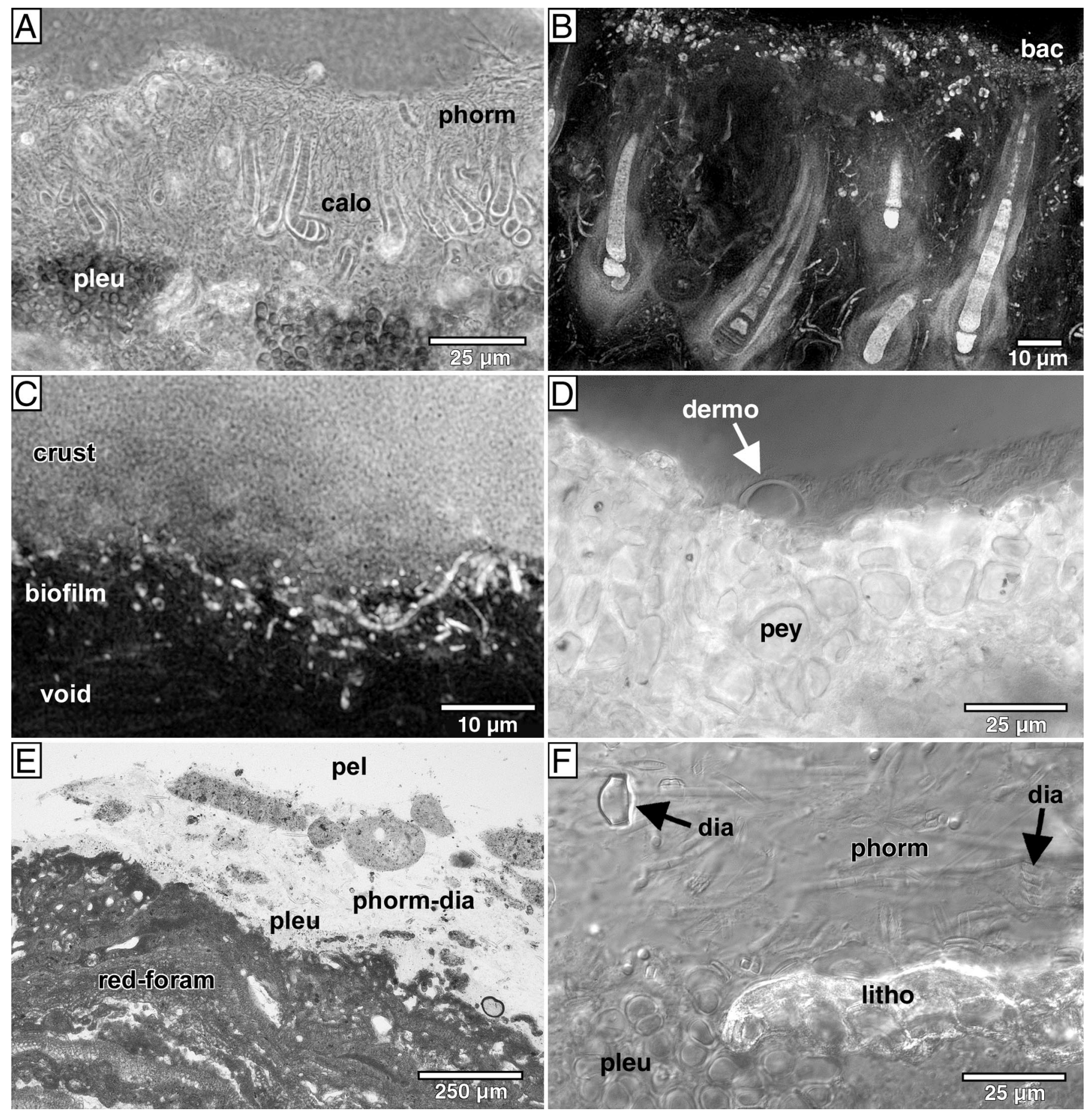

FIG. 10.-Hardpart sections of reef-surface biota and biofilms of the wet season, June 1996. A) Vertical section of a reef-top biofilm showing Calothrix filaments (calo) within a plexus of Phormidium filaments (phorm). The coccoid Pleurocapsa (pleu) preferentially occurs near the contact with the hard substrate. $0.3 \mathrm{~m}$ depth, reef \#1 Phase contrast. Sample Sat 96/14. B) Upper part of reef-surface biofilm at $0.6 \mathrm{~m}$ depth. Numerous bacteria occur at the top of the Calothrix-Phormidium biofilm. Reef \#1. Deconvolved epifluorescence micrograph (ex 450-490 nm, em 520-575 nm), Sample Sat 96/15. C) 10- $\mu \mathrm{m}$-thick biofilm of non-phototrophic bacteria (biofilm) upon a laminated crust (crust) within the void of the fossil green-algal-microbialite framestone of the reef tops. $0.6 \mathrm{~m}$ depth, reef \#1. Deconvolved epifluorescence micrograph (ex 450-490 nm, em 520-575 nm). Sample Sat 96/15. D) Non-calcified bacterial biofilm with scattered hemispherical algae ("Dermocarpella") (dermo) upon a living Peyssonnelia crust (pey) of the reef surface. $5 \mathrm{~m}$ depth, reef \#1a. Nomarski optics. Sample Sat 93/3. E) Soft Phormidium-diatom biofilm (phorm-dia) with basal Pleurocapsa layer (pleu) and trapped fecal pellets (pel) upon dead red-algal-foraminiferal crust (red-foram). $17 \mathrm{~m}$ depth, reef \#1a. Transmitted light. Sample Sat 96/31. F) Nonmineralized reef-surface biofilm composed of prostrate Phormidium filaments (phorm) and diatoms (dia) at $17 \mathrm{~m}$ depth. Basal biofilm parts on the dead red-algalforaminiferal crusts are formed by Pleurocapsa and dead Lithoporella (litho). Reef \#1a. Nomarski optics. Sample: Sat96/31-AO. 


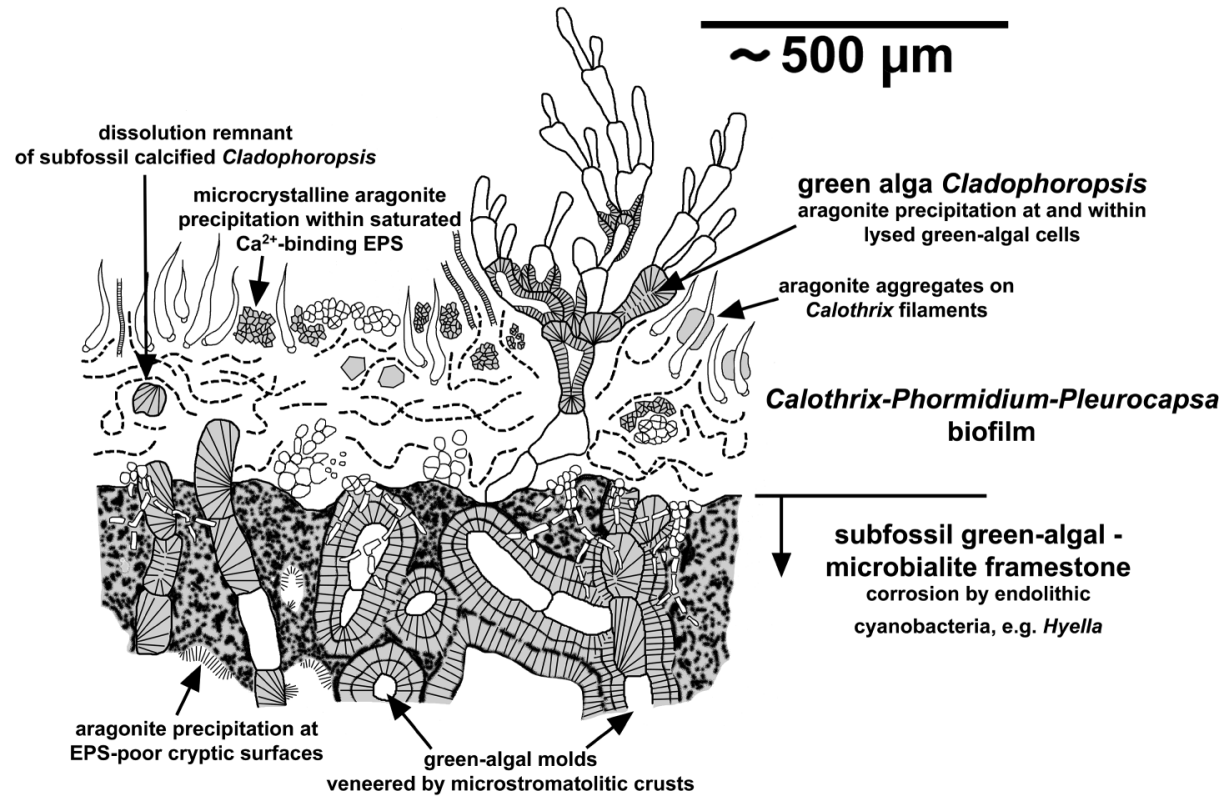

FIg. 11.-Schematic diagram of a green-algal microbialite and recent aragonite precipitates within the Phormidium-Calothrix-Pleurocapsa zone at the seasonally exposed reef tops, wet season, June 1996. tests of nubecullinid foraminifera. Only monostromatous thalli of Lithoporella at the crust surface were observed still living.

The yellowish-brown biofilms, 75-400 $\mu \mathrm{m}$ thick, are composed of a plexus of prostrate Phormidium filaments with abundant pennate diatoms (Fig. 10E, F). Phormidium is represented exclusively by trichomes $2 \mu \mathrm{m}$ thick. Basal biofilm sections and subsurface voids of the crusts locally show abundant colonies of coccoid cyanobacteria (mainly Pleurocapsa; Fig. 10F). The coccoid alga "Dermocarpella" occurs preferentially at places of reduced biofilm thickness. Numerous detrital particles, such as diatoms, foraminifera, sponge spiculae, Mn particles, and fecal pellets, are trapped by the mucilaginous biofilm (Fig. 10E). Millimeter- to centimeter-size voids and cryptic reef rock cavities show micritic veneers and Mn hydroxide impregnations identical to those of the previously described zone.

\section{Recent $\mathrm{CaCO}_{3}$ Precipitates of Reef-Surface Biofilms and Voids}

Five types of $\mathrm{CaCO}_{3}$ precipitates considered to be of recent age were recognized in subsurface voids of the reefs and reef-top samples collected in October 1993 and June 1996. None of these precipitates was abundant, except for fibrous aragonite at and within green-algal filaments and microcrystalline precipitates within reef-top biofilms of June 1996.

(1) Fibrous Aragonite at and within Green-Algal Filaments.-Calcification linked to green-algal tufts was observed only in samples from the seasonally flooded reef tops between 0.3 and $0.9 \mathrm{~m}$ depth in June 1996 (Fig. 12A-D) and in one sample of October 1993 taken at $0.5 \mathrm{~m}$ depth (Fig. 8A). Within the Phormidium-Calothrix-Pleurocapsa biofilms, basal cells and holdfasts of Cladophoropsis often show internal fibrous aragonite, even when adjacent cells are still living. Some internally calcifying cells even show vesicular cellular remains (Fig. 12A, B), and therefore must have died only a short time before. This observation is considered unequivocal evidence for precipitation concurrent with the time of sampling. Acicular to botryoid aragonite grows perpendicular from the internal cell wall to the center of the cells (Fig. 12C, D). Calcification occasionally proceeds also at the outer cell surface to form local, thin, fibrous veneers. Partly disintegrated cells are characterized by flat botryoids attached to the inner cell wall surface (Fig. 12B, D). Electron microprobe analyses indicate an aragonite mineralogy with 98.3 mole $\% \mathrm{CaCO}_{3}$ (47.2 wt \% $\mathrm{CaO}$ ), 10600 ppm $\mathrm{Sr}\left(1.25\right.$ wt \% SrO), and $\mathrm{MgCO}_{3}$ less than 0.4 mole \% (Table 2).

(2) Microcrystalline Precipitates within Phormidium-CalothrixPleurocapsa Biofilms.- The same reef-top samples of the wet season show microcrystalline aggregates scattered within the mucus of the PhormidiumCalothrix-Pleurocapsa biofilms (Fig. 12E, F). These microclots occur preferentially at or near the contact with the liquid phase, without spatial linkage to living or dead cyanobacterial trichomes or coccoid colonies (Fig. $12 \mathrm{E}, \mathrm{F})$. In only five instances did we observe microcrystalline aragonite, which formed immediately at one side of living Pleurocapsa colonies. Electron microprobe analyses indicate an aragonite mineralogy of the microcrystalline aggregates, with 97.7 mole $\% \mathrm{CaCO}_{3}(50.0$ wt $\% \mathrm{CaO})$, $11300 \mathrm{ppm} \mathrm{Sr}(1.34$ wt \% $\mathrm{SrO})$, and $\mathrm{MgCO}_{3}$ less than 0.9 mole \% (Table 2).

(3) Semitubular Aragonite Aggregates around Calothrix Trichomes.-Three observations of semitubular aragonite aggregates at $\mathrm{Cal}$ othrix filaments, co-occurring with microcrystalline precipitates, were made in reef-top samples of the wet season of June 1996 (Arp et al. 1999b). The aggregates are $30 \mu \mathrm{m}$ long and $25 \mu \mathrm{m}$ wide, thereby partly enclosing middle trichome parts. These exceptional cases provide the only clear evidence for a spatial linkage of precipitates and living cyanobacteria in Lake Satonda. The rounded semitubular aragonite aggregates resemble "aragonite concretions" of perimarine Rivularia as described by Golubić and Campbell (1981).

(4) Microcrystalline Precipitates within Fecal Pellets.-Soft fecal pellets trapped in mucilaginous Phormidium-diatom biofilms from $23 \mathrm{~m}$ depth (Fig. 10E; wet season June 1996) show microcrystalline aggregates 10-20 $\mu \mathrm{m}$ in size within their organic matrix. Electron microprobe analyses indicate a high- $\mathrm{Mg}$ calcite mineralogy with 76.4 mole $\% \mathrm{CaCO}_{3}(42.4$ wt \% $\mathrm{CaO}$ ), $2000 \mathrm{ppm} \mathrm{Sr}\left(0.23\right.$ wt $\% \mathrm{SrO}$ ), and 23 mole $\% \mathrm{MgCO}_{3}$ (9 wt \% $\mathrm{MgO}$ ) (Table 2). These aggregates are assumed to have formed within the pellets and were the only evident high-Mg calcitic precipitates found in reef-surface biofilms of 1993 and 1996.

(5) Fibrous Aragonite within Near-Surface Voids.-Subsurface voids immediately below to a few millimeters below the living red algae and biofilms at $0.3-0.9 \mathrm{~m}$ depth occasionally reveal fans of acicular and botryoid aragonite (Fig. 13A, B). Though there is no direct evidence for concurrent formation, they appear recently formed because of their delicate needles and lack of endolithic borings, micritization, and attached organics or bacteria. Fabric and composition are identical to those observed within dead green-algal cells of Cladophoropsis described above. The corresponding voids are almost free of biofilms, with only minor or light-optically undetectable organic veneers. Similar fibrous aragonite cements occur within lysed resting bodies of hydromerid sponge (Fig. 13C, D). 

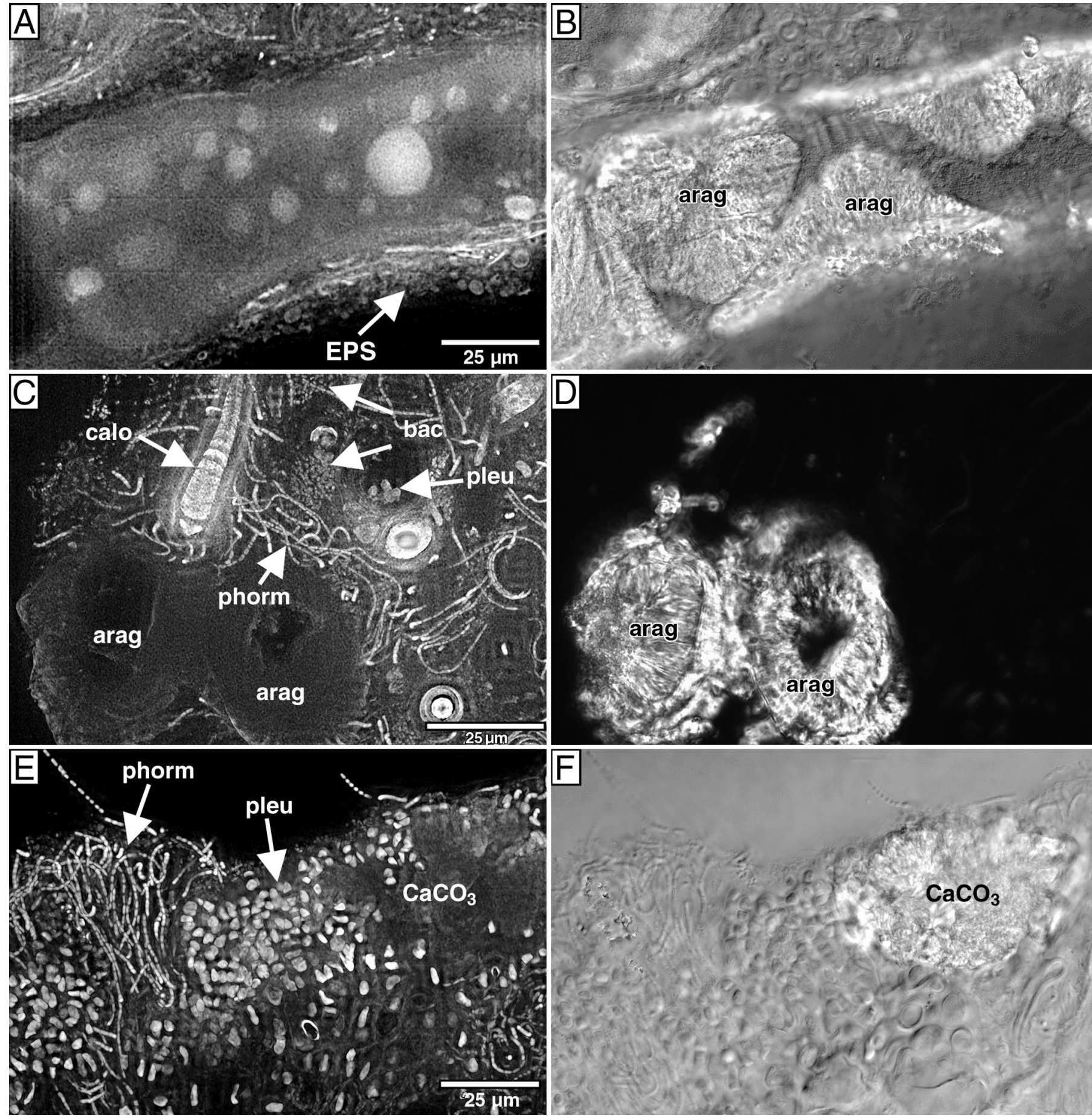

FIg. 12. $-\mathrm{CaCO}_{3}$ precipitates in biofilms of the wet season, June 1996. A) Dead, decaying green-algal filament cell showing vesicles and lipid droplets. Note that no bacteria are involved in cell decay at this stage of autolysis. The external cell wall is covered by biofilm EPS (arrow), considered to inhibit $\mathrm{CaCO}_{3}$ precipitation. $0.9 \mathrm{~m}$ depth, reef \#1. Deconvolved epifluorecence micrograph (ex 450-490 nm, em 520-575 nm). Sample Sat 96/19. B) Same view as in part A, to show the internal nucleation and growth of aragonite fans (arag) upon death of the green-algal cell. $0.9 \mathrm{~m}$ depth, reef \#1. Nomarski optics. Sample Sat 96/19. For scale see part A. C) Oblique section of a Phormidium-Calothrix-Pleurocapsa biofilm with cross-sections of internally calcified green-algal filaments (arag). Note non-phototrophic bacteria (bac) within the EPS. $0.6 \mathrm{~m}$ depth, reef \#1. Deconvolved epifluorescence micrograph (ex 450-490 nm, em 520-575 nm). Sample Sat 96/16. D) Same view as in part C under crossed nicols to show internal fibrous aragonite (arag) of lysed green-algal filament cells. $0.6 \mathrm{~m}$ depth, reef \#1. Sample Sat 96/16. For scale see part C. E) Detail of the uppermost part of a reef-top biofilm comprising the cyanobacterial genera Phormidium (phorm) and Pleurocapsa (pleu). The microcrystalline aragonite aggregate $\left(\mathrm{CaCO}_{3}\right)$ at the contact with the open lake water nucleated within the EPS without spatial relation to the filamentous and coccoid cyanobacteria. $0.6 \mathrm{~m}$ depth, reef \#1. Deconvolved epifluorescence micrograph (ex 450-490 nm, em 520-575 nm). Sample Sat 96/16. F) Same view as in part E by Nomarski optics to show the aragonite aggregate $\left(\mathrm{CaCO}_{3}\right)$. $0.6 \mathrm{~m}$ depth, reef \#1. Sample Sat 96/16. For scale see part E. 
TABLE 2.-Electron microprobe analysis of recent precipitates associated with reef surface biofilms, Satonda Crater Lake.

\begin{tabular}{|c|c|c|c|c|c|c|c|c|}
\hline Sample & Water Depth & Comments & Spot No. & $\begin{array}{c}\mathrm{CaO} \\
{[\mathrm{wt} \%]}\end{array}$ & $\begin{array}{c}\mathrm{SrO} \\
{[\mathrm{wt} \%]}\end{array}$ & $\begin{array}{l}\mathrm{MgO} \\
{[\mathrm{wt} \%]}\end{array}$ & $\begin{array}{c}\mathrm{SiO} \\
{[\mathrm{wt} \%]}\end{array}$ & Phase \\
\hline Sat96/14 & $0.3 \mathrm{~m}$ & microcrystalline aggregate \#1 & 2 & $51.7 \pm 0.2$ & $1.46 \pm 0.02$ & $0.18 \pm 0.01$ & - & aragonite \\
\hline Sat96/14 & $0.3 \mathrm{~m}$ & microcrystalline aggregate \#2 & 3 & $50.0 \pm 0.2$ & $1.39 \pm 0.02$ & $1.11 \pm 0.01$ & - & aragonite \\
\hline Sat96/14 & $0.3 \mathrm{~m}$ & microcrystalline aggregate \#3 & 4 & $50.4 \pm 0.2$ & $1.36 \pm 0.02$ & $0.24 \pm 0.01$ & - & aragonite \\
\hline Sat96/14 & $0.3 \mathrm{~m}$ & microcrystalline aggregate \#4 & 5 & $49.5 \pm 0.2$ & $1.38 \pm 0.02$ & $0.25 \pm 0.01$ & - & aragonite \\
\hline Sat96/14 & $0.3 \mathrm{~m}$ & microcrystalline aggregate $\# 5$ & 6 & $49.8 \pm 0.2$ & $1.36 \pm 0.02$ & $0.18 \pm 0.01$ & - & aragonite \\
\hline Sat96/14 & $0.3 \mathrm{~m}$ & microcrystalline aggregate \#6 & 7 & $51.7 \pm 0.2$ & $1.21 \pm 0.02$ & $0.16 \pm 0.01$ & - & aragonite \\
\hline Sat96/14 & $0.3 \mathrm{~m}$ & microcrystalline aggregate \#7 & 8 & $50.6 \pm 0.2$ & $1.28 \pm 0.02$ & $0.38 \pm 0.01$ & - & aragonite \\
\hline Sat96/14 & $0.3 \mathrm{~m}$ & microcrystalline aggregate \#8 & 9 & $51.2 \pm 0.2$ & $1.41 \pm 0.02$ & $0.18 \pm 0.01$ & - & aragonite \\
\hline Sat96/14 & $0.3 \mathrm{~m}$ & microcrystalline aggregate \#9 & 11 & $51.0 \pm 0.2$ & $1.29 \pm 0.02$ & $0.35 \pm 0.01$ & - & aragonite \\
\hline Sat96/14 & $0.3 \mathrm{~m}$ & microcrystalline aggregate \#10 & 16 & $44.4 \pm 0.2$ & $1.23 \pm 0.02$ & $0.23 \pm 0.01$ & - & aragonite \\
\hline Sat96/14 & $0.3 \mathrm{~m}$ & cement green algal filament \#1 & 10 & $47.7 \pm 0.2$ & $1.15 \pm 0.02$ & $0.14 \pm 0.02$ & $2.43 \pm 0.05$ & aragonite + silica \\
\hline Sat96/14 & $0.3 \mathrm{~m}$ & cement green algal filament \#2 & 12 & $46.8 \pm 0.2$ & $1.15 \pm 0.02$ & $0.10 \pm 0.02$ & - & aragonite \\
\hline Sat96/14 & $0.3 \mathrm{~m}$ & cement green algal filament \#3 & 13 & $47.8 \pm 0.2$ & $1.31 \pm 0.02$ & $0.08 \pm 0.02$ & - & aragonite \\
\hline Sat96/14 & $0.3 \mathrm{~m}$ & cement green algal filament \#4 & 14 & $47.5 \pm 0.2$ & $1.32 \pm 0.02$ & $0.11 \pm 0.02$ & - & aragonite \\
\hline Sat96/14 & $0.3 \mathrm{~m}$ & cement green algal filament \#5 & 15 & $46.5 \pm 0.2$ & $1.33 \pm 0.02$ & $0.11 \pm 0.02$ & - & aragonite \\
\hline Sat96/31 & $17 \mathrm{~m}$ & precipitate within fecal pellet \#1 & 17 & $42.4 \pm 0.2$ & $0.23 \pm 0.01$ & $9.34 \pm 0.00$ & - & high-Mg-calcite \\
\hline Sat $96 / 31$ & $17 \mathrm{~m}$ & detrital component within fecal pellet \#1 & 18 & $14.0 \pm 0.1$ & $0.68 \pm 0.02$ & $0.05 \pm 0.02$ & $45.05 \pm 0.22$ & detr. silicate \\
\hline Sat $96 / 31$ & $17 \mathrm{~m}$ & precipitate within fecal pellet \#2 & 19 & $48.8 \pm 0.2$ & $1.03 \pm 0.02$ & $0.22 \pm 0.01$ & - & aragonite \\
\hline
\end{tabular}
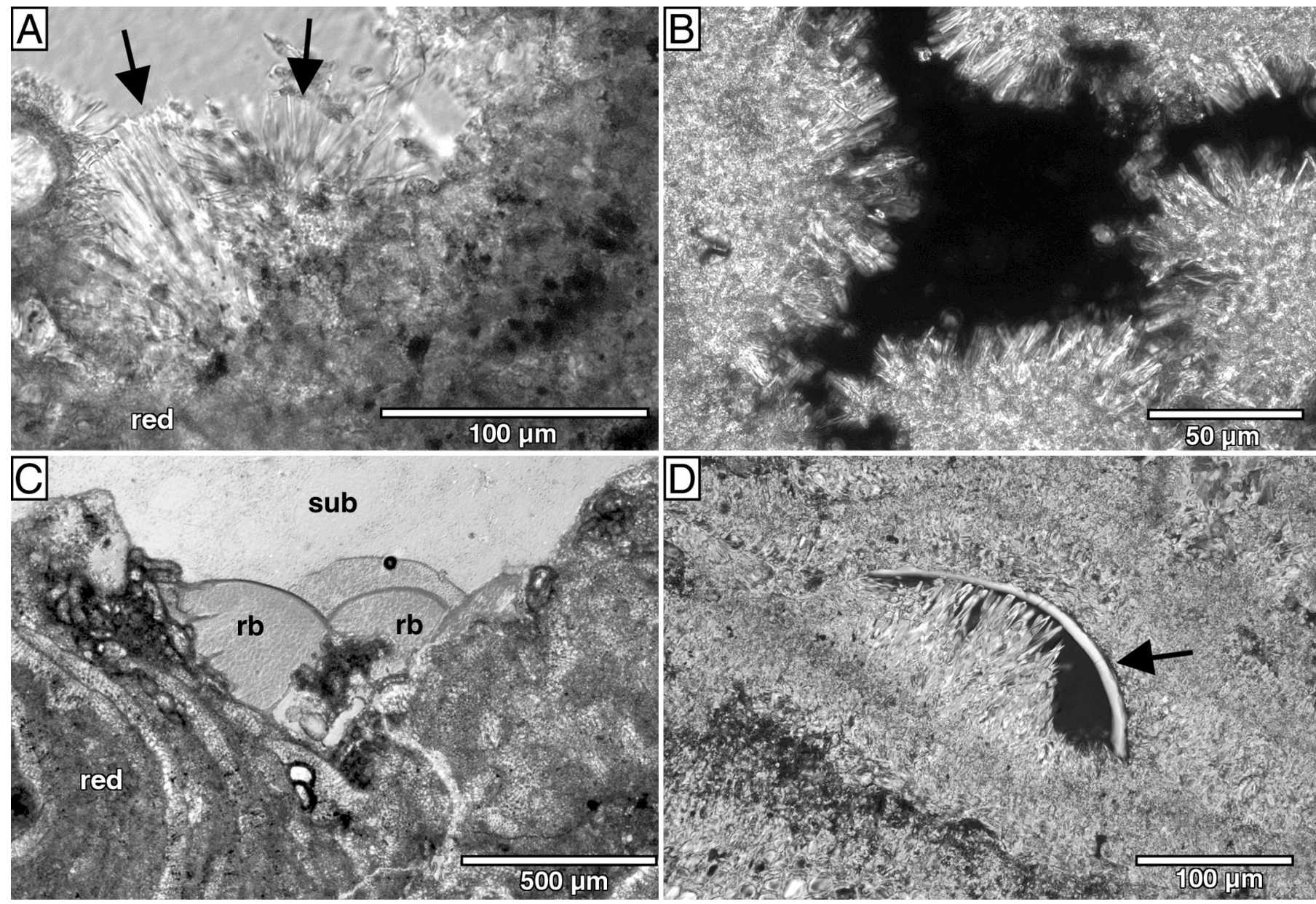

FIG. 13.-Recent aragonite needle precipitates and Wetheredella-like structures (sponge resting body), Satonda Crater Lake, Indonesia. A) Fans of acicular aragonite (arrows) within a void of the red-algal framework (red). 0.9 m depth, reef \#1. Plane-polarized light. Sample Sat 96/20. B) Acicular aragonite within a void of a greenalgal-microbialite framestone of the reef top. Very recent formation of these precipitates is assumed. $0.3 \mathrm{~m}$ depth, reef \#1. Crossed nicols. Sample Sat 96/14. C) Hadromerid sponge Laxosuberites (sub) with resting bodies (rb) containing archaeocytes. Resting bodies form preferentially in depressions and cavities of the red-algal reef framework (red). $14 \mathrm{~m}$ depth, reef \#10. Nomarski optics. Sample Sat 93/69. D) Subfossil, lysed sponge resting body encased within dense Peyssonnelia crust. The resting body is partly filled with fibrous aragonite radiating from the carbonate base. Note that no nucleation occurred at the spongin of the organic wall (labeled by green-fluorescing Acridine Orange; arrow) of the cyst. $7 \mathrm{~m}$ depth, reef \#1. Overlay of crossed-nicols view and epifluorescence image (ex 450-490 nm, em 520-575 nm). Sample Sat 93/6. 


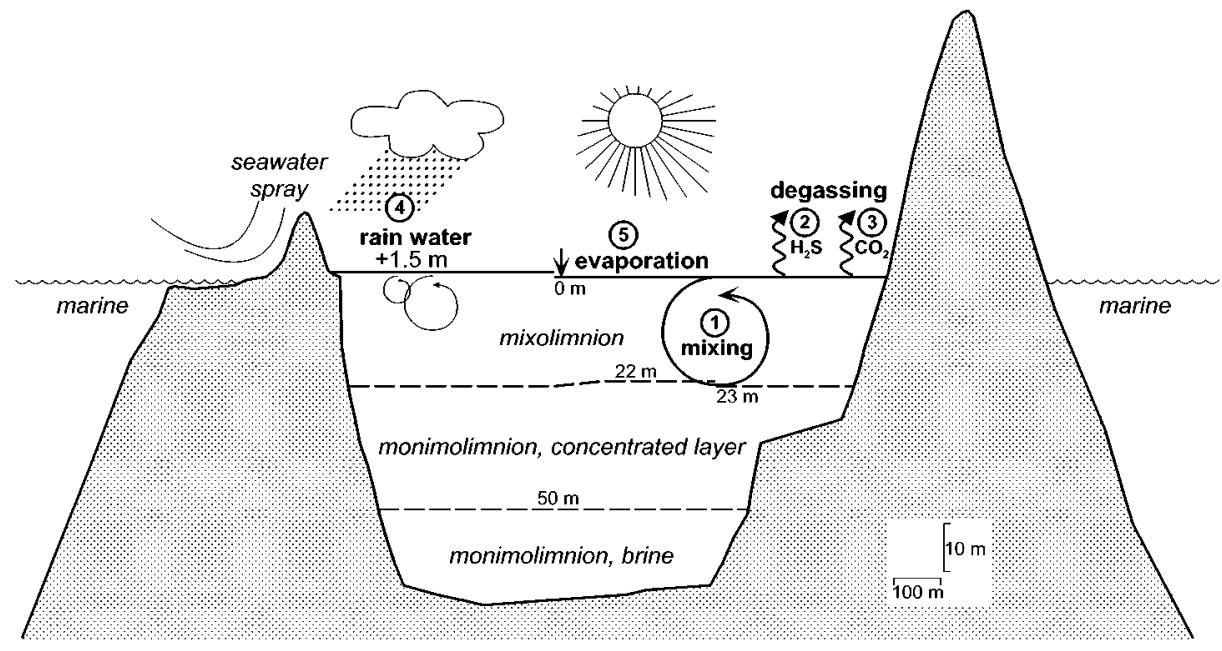

FIG. 14.-Idealized limnological cycle of the Satonda crater lake used for hydrochemical model calculations. The cycle starts at the mixis at end of dry season (1), associated with $\mathrm{H}_{2} \mathrm{~S}(2)$ and $\mathrm{CO}_{2}$ degassing (3). Wet-season conditions are simulated by addition of rain water mixed with $1 \mathrm{wt} \%$ seawater spray (4). Evaporation during the dry season reduces the volume of the water body to its initial value. Steps (1), (2), and (3) have been calculated separately, though they occur simultaneously in nature.

\section{Modeling of Factors Driving $\mathrm{CaCO}_{3}$ Precipitation in Satonda Crater Lake}

To assess effects of hydrochemical and microbiological factors on modern $\mathrm{CaCO}_{3}$ precipitation in Lake Satonda, model calculations were performed using the program PHREEQC (Parkhurst 1995). The first calculations focus on seasonal mixis of mixolimnion and upper monimolimnion waters, degassing, and evaporation. The second group of models explores several simplified pathways of EPS degradation, which can influence $\mathrm{CaCO}_{3}$ precipitation.

(1) Modeling of Satonda Crater Lake Hydrochemical Cycle.-Data from the end of the dry season in October 1993 are used as initial parameters. The simulation included five steps, as follows: (1) mixing of mixolimnion and the top layer of monimolimnion, followed by (2) $\mathrm{H}_{2} \mathrm{~S}$ degassing, (3) $\mathrm{CO}_{2}$ degassing, (4) addition of, and mixing with, $1.5 \mathrm{~m}$ of rain water with $1 \mathrm{vol} \%$ seawater spray, and finally (5) evaporation to return to the initial lake level (Fig. 14, Table 3).

Step 1 refers to the end of the dry season, when the density of the surface waters surpasses that of the underlying water layers. In years of moderate evaporation, mixis includes only the uppermost meter of the monimolimnion concentrated layer (Table 3: model calculation 1). However, in years with a more pronounced dry season, mixis may reach down to $27 \mathrm{~m}$ depth (Table 3: model calculation 2), as indicated by a remnant anomaly of the salinity profile at that depth in October 1993. Degassing of $\mathrm{CO}_{2}$ and $\mathrm{H}_{2} \mathrm{~S}$ begins immediately after mixis starts but has been calculated separately to show the effect of each process. Although $\mathrm{CO}_{2}$ degassing certainly occurs each year, $\mathrm{H}_{2} \mathrm{~S}$ degassing may be replaced fully or partly by oxidation of $\mathrm{H}_{2} \mathrm{~S}$ to $\mathrm{S}^{0}$ and $\mathrm{SO}_{4}{ }^{2-}$ in the upper water column. This should be true for years of moderately deep mixis. Thus the model shows only the maximum effect to raise $\mathrm{CaCO}_{3}$ supersaturation. Step 4 simulates rain-water supply during the wet season. To include a reasonable input of ions from outside the lake, seawater spray has been included at 1 vol \% of rain water. A lake-level rise of $1.5 \mathrm{~m}$ is derived from highstand marks observed in June 1996. Input from weathering solutions derived from the crater wall is assumed to be negligible. Step 5 refers to evaporation during the course of the dry season to reach the initial lake-water volume.

Results of the model calculations are shown in Table 3. Mixing the monimolimnion top layer and the mixolimnion results in a decrease in $\mathrm{CaCO}_{3}$ supersaturation. $\mathrm{H}_{2} \mathrm{~S}$ degassing remains without substancial effect on the $\mathrm{CaCO}_{3}$ supersaturation, whereas $\mathrm{CO}_{2}$ degassing raises the $\mathrm{SI}_{\mathrm{Cc}}$ and $\mathrm{SI}_{\text {Arag }}$ to values above 1.0, thereby causing precipitation (Table 3). Addition of rain water and seawater spray again lowers supersaturation. Final evaporation, if equal to the volume added by rainwater, reestablishes initial conditions, because additon of ions by rain and seawater spray is minor (Table 3).

With regard to mass-balance considerations, model calculation 1 shows that the amount of $\mathrm{CaCO}_{3}$ that should precipitate from $\mathrm{CO}_{2}$ degassing $\left(21.63 \times 10^{6} \mathrm{~g}\right.$ aragonite for 1996 ; step 3 ; Table 3$)$ is numerically slightly lower than the amount of $\mathrm{CaCO}_{3}$ actually deposited within reef-top biofilms $\left(25.32 \times 10^{6} \mathrm{~g} \mathrm{CaCO}_{3}\right.$ for 1996; Table 4). However, within the given range of error both amounts are approximately the same. By contrast, years of more pronounced seasonality with mixis reaching to greater depth (model calculation 2; Table 3 ) would produce substantially more $\mathrm{CaCO}_{3}(109.85$ $\times 10^{6} \mathrm{~g}$ aragonite) compared to 1996 .

(2) Modeling of EPS Degradation and Secondary $\mathrm{Ca}^{2+}$ Release.Secondary $\mathrm{Ca}^{2+}$ release from degradation of acidic exopolymers has been suggested to contribute to $\mathrm{CaCO}_{3}$ precipitation in microbial mats of hypersaline lakes (Trichet and Défarge 1995), spring-mound biofilms of alkaline lakes (Arp et al. 1998), and marine stromatolites (Visscher et al. 2000). Therefore model calculations were performed to test if secondary $\mathrm{Ca}^{2+}$ release also contributes to calcification in Lake Satonda biofilms. A range from low-DIC/high-Ca ${ }^{2+}$ to high-DIC/low- $\mathrm{Ca}^{2+}$ waters was generated by addition of $\mathrm{Ca}^{2+}$ or $\mathrm{HCO}_{3}{ }^{-}$to mean Satonda mixolimnion water and readjustment to $\mathrm{SI}_{\text {Arag }}=0.86$ und $\mathrm{pCO}_{2}=10^{-3.57}$ atm (Fig. 15).

In model 1 (Figure 15), $1 \mathrm{mmol} \mathrm{L}^{-1} \mathrm{Ca}^{2+}$ and $2 \mathrm{mmol} \mathrm{L}^{-1}$ DIC were added to simulate enzymatic decarboxylation. This may occur either extracellularly prior to depolymerization, or intracellularly after hydrolysis of polymer chains and uptake by the bacterial cells. One reason for the $\mathrm{Ca}^{2+}$ addition is that $0.87-30.3 \mathrm{mg} \mathrm{Ca}^{2+}$ per $\mathrm{g}$ dry weight can be complexed by various polysaccharides at neutral $\mathrm{pH}$ (Debon and Tester 2001). This means that $0.2175-7.575 \mathrm{mmol} \mathrm{Ca}^{2+}$ can be bound within 1 liter of hydrated polysaccharides (assuming a hydrated EPS matrix with $1 \mathrm{wt} \%$ polysaccharide molecules, which are, for simplification, composed of hexose monomers). Second, one $\mathrm{Ca}^{2+}$ is bound by two carboxylate groups. The latter are released as $\mathrm{CO}_{2}$ with charge balance maintained by $\mathrm{H}^{+}$addition to the remaining pentose monomer.

Model 2/3 (Figure 15A, B) includes the addition of $10 \mathrm{mmol} \mathrm{L}^{-1} \mathrm{CO}_{2}$ in two reaction steps to simulate a hypothetical aerobic $50 \%$ and $100 \%$ degradation of the remaining pentose monomers. This is because $10 \mathrm{C}$ atoms correspond to 2 carboxylate and $1 \mathrm{Ca}^{2+}$ in the initial acidic polysaccharide gel. Model 1 and 2/3 also accounts for aerobic oxidation of hexuronic acid (e.g., glucuronate) after enzymatic reduction of the carboxylate group (Sutherland 1977). However, conversion of pentose (e.g., xylopyranose) commonly proceeds via fermentation.

Model 4 (Figure 15A, C) accounts for fermentation, which would release 
TABLE 3.-Hydrochemical model calculation of seasonal mixis, $\mathrm{CO}_{2}$ and $\mathrm{H}_{2} \mathrm{~S}$ degassing, rain-water addition, and evaporation. Amount of CaCO $\mathrm{CO}_{3}$ precipitated has been calculated from differences between $\mathrm{Ca}^{2+}$ and DIC concentrations after $\mathrm{CO}_{2}$ degassing and after equilibration to $\mathrm{SI}_{C \mathrm{C}}=1.0$.

\begin{tabular}{|c|c|c|c|c|c|c|c|c|c|c|c|c|c|c|c|c|c|c|}
\hline \multicolumn{19}{|c|}{ Model calculation 1: Seasonal cycle including uppermost $1 \mathrm{~m}$ of monimolimnion (i.e., water $22-23 \mathrm{~m}$ depth) } \\
\hline & $\begin{array}{c}\text { Depth } \\
\text { [m] }\end{array}$ & $\begin{array}{l}\text { Volume } \\
{\left[\mathrm{m}^{3}\right]}\end{array}$ & $\begin{array}{c}\text { Fractions } \\
\text { During } \\
\text { Mixing }\end{array}$ & $\begin{array}{c}\mathrm{T} \\
{\left[{ }^{\circ} \mathrm{C}\right]}\end{array}$ & $\mathrm{pH}$ & $\mathrm{p} \varepsilon$ & $\begin{array}{l}\text { Total Alk } \\
{\left[\text { meq L } \mathrm{L}^{-1}\right]}\end{array}$ & DIC & $\mathrm{Na}^{+}$ & $\mathrm{K}^{+}$ & $\begin{array}{l}\mathrm{Ca}^{2+} \\
{[\mathrm{mmol}}\end{array}$ & $\underset{\left.\mathrm{L}^{-1}\right]}{\mathrm{Mg}^{2+}}$ & $\mathrm{Cl}^{-}$ & $\mathrm{SO}_{4}{ }^{2-}$ & $\mathrm{H}_{2} \mathrm{~S}$ & $\mathrm{SI}_{\mathrm{Cc}}$ & $\mathrm{SI}_{\text {Arag }}$ & $\begin{array}{r}\mathrm{pCO}_{2} \\
{[\mu \mathrm{atm}]}\end{array}$ \\
\hline step 1 & initial mixolimnion (mean) 0-22 m depth & 15990754 & 0.9621 & 30.8 & 8.58 & 4.30 & 4.158 & 3.375 & 418.6 & 11.53 & 4.58 & 42.58 & 483.1 & 18.63 & 0.00 & 1.00 & 0.86 & 269 \\
\hline step 1 & water $22-23 \mathrm{~m}$ depth & 630481 & 0.0379 & 30.6 & 8.24 & -0.05 & 4.45 & 4.001 & 441.2 & 12.34 & 4.85 & 44.38 & 510.4 & 18.55 & 0.02 & 0.80 & 0.66 & 813 \\
\hline step 1 & $\begin{array}{l}\text { new mixolimnion } 0-23 \mathrm{~m} \\
\downarrow\end{array}$ & 16621235 & 1.0000 & 30.8 & 8.58 & -5.10 & 4.193 & 3.399 & 423.4 & 11.62 & 4.625 & 42.97 & 488.5 & 18.76 & 0.0008 & 1.00 & 0.86 & 282 \\
\hline step 2 & new mixolimnion 0-23 m & 16621235 & & 30.8 & 8.58 & -5.10 & 4.193 & 3.399 & 423.4 & 11.62 & 4.625 & 42.97 & 488.5 & 18.76 & 0.0008 & 1.00 & 0.86 & 282 \\
\hline step 2 & after $\mathrm{H}_{2} \mathrm{~S}$ degassing & 16621235 & & 30.8 & 8.58 & 4.41 & 4.193 & 3.399 & 423.4 & 11.62 & 4.625 & 42.97 & 488.5 & 18.76 & 0.00 & 1.00 & 0.85 & 282 \\
\hline step 2 & $\mathrm{CaCO}_{3}$ precipitation (none) & 16621235 & & & & & & & & & & & & & & & & \\
\hline step 3 & after $\mathrm{Co}_{2}$ degassing & 16621235 & & 30.8 & 8.59 & 4.43 & 4.193 & 3.380 & 423.4 & 11.62 & 4.625 & 42.97 & 488.5 & 18.76 & 0.00 & 1.01 & 0.87 & 269 \\
\hline step 3 & after $\mathrm{CaCO}_{3}$ precipitation & 16621235 & & 30.8 & 8.59 & 4.45 & 4.167 & 3.367 & 423.4 & 11.62 & 4.612 & 42.97 & 488.5 & 18.76 & 0.00 & 1.00 & 0.86 & 275 \\
\hline step 4 & rain water and seawater spray $+1.5 \mathrm{~m}$ & 1202182 & 0.0674 & 25.0 & 7.00 & 4.06 & 0.024 & 0.029 & 4.9 & 0.11 & 0.107 & 0.55 & 5.7 & 0.29 & 0.00 & -3.64 & -3.79 & 145 \\
\hline step 4 & after addition of rain water/seawater spray & 17823416 & 1.0000 & 30.5 & 8.61 & 4.49 & 3.888 & 3.142 & 395.2 & 10.84 & 4.308 & 40.11 & 456.0 & 17.51 & 0.00 & 0.97 & 0.83 & 245 \\
\hline step 5 & after evaporation to initial volume & 16621235 & 0.9326 & 30.8 & 8.59 & 4.50 & 4.169 & 3.370 & 423.8 & 11.63 & 4.620 & 43.01 & 489.0 & 18.78 & 0.00 & 1.00 & 0.86 & 2.75 \\
\hline
\end{tabular}

Result of model calculation 1: Amount of $\mathrm{CaCO}_{3}$ precipitated

\begin{tabular}{|c|c|c|c|c|c|c|c|}
\hline$\underset{\left[\mathrm{km}^{3}\right]}{\text { Mixolimnion Volume }}$ & $\begin{array}{c}\Delta \mathrm{Ca}^{2+}(\text { step } 3) \\
{\left[\mathrm{mol} \mathrm{L}^{-1}\right]}\end{array}$ & $\begin{array}{c}\Delta \mathrm{Ca}^{2+}(\text { step } 3) \\
{[\mathrm{mol}]}\end{array}$ & $\begin{array}{c}\Delta \text { DIC (step 3) } \\
{\left[\mathrm{mol} \mathrm{L}^{-1}\right]}\end{array}$ & $\begin{array}{c}\Delta \mathrm{CO}_{3}{ }^{2-} \text { (step 3) } \\
{[\mathrm{mol}]}\end{array}$ & $\begin{array}{c}\mathrm{Ca}^{2+} \text { precipitated } \\
{\left[\times 10^{6} \mathrm{~g}\right]}\end{array}$ & $\begin{array}{c}\mathrm{CO}_{3}{ }^{2-} \text { precipitated } \\
{\left[\times 10^{6} \mathrm{~g}\right]}\end{array}$ & $\begin{array}{c}\mathrm{CaCO}_{3} \text { precipitated } \\
{\left[\times 10^{6} \mathrm{~g}\right]}\end{array}$ \\
\hline 0.0166 & 0.000013 & 216076 & 0.000013 & 216076 & 8.66 & 12.97 & 21.63 \\
\hline
\end{tabular}

Model calculation 2: Seasonal cycle including uppermost $5 \mathrm{~m}$ of monomolimnion (i.e., water $22-27 \mathrm{~m}$ depth)

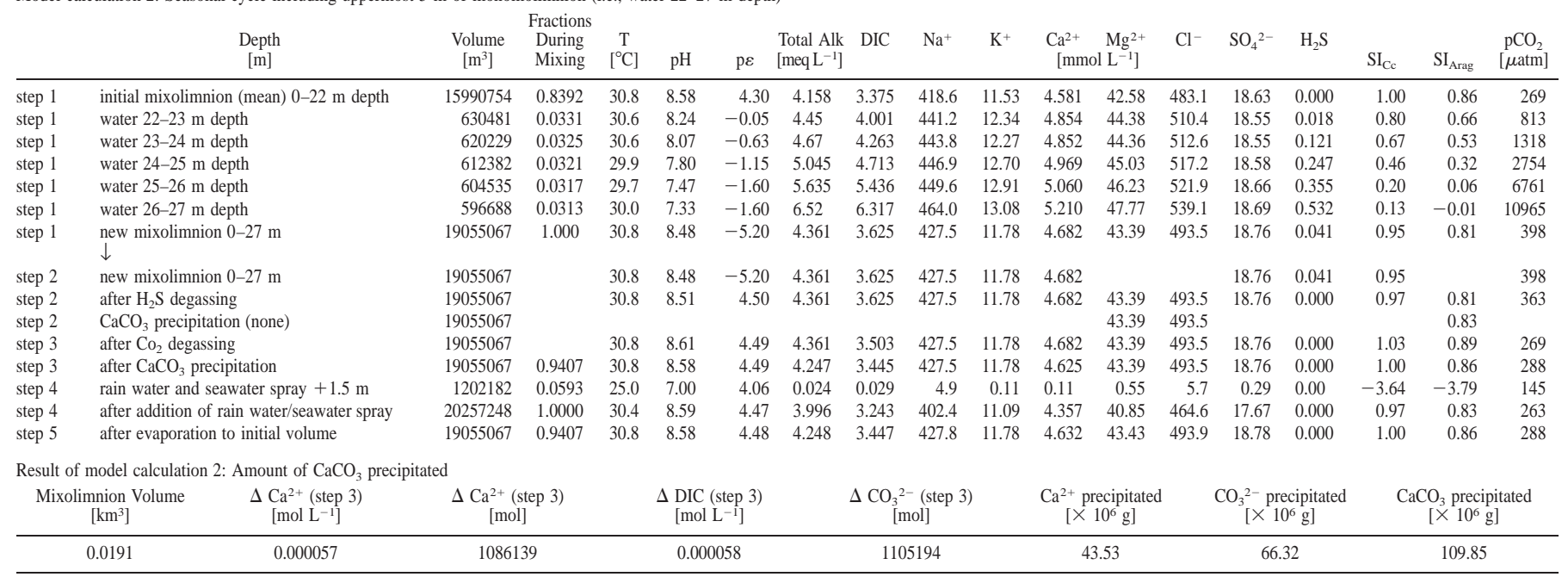

$3 \mathrm{CO}_{2}$ (plus $2 \mathrm{CH}_{4}$ and $1 \mathrm{H}_{2}$ ) from one pentose monomer. Finally, Model 5 (Figure 15A, C) simulates EPS degradation via sulfate reduction, which uses organic acids from incomplete fermentation (e.g., acetate and lactate). In this case, sulfate reduction releases 5 bicarbonate and $2 \frac{1}{2}$ sulfide concurrently with the removal of $2 \frac{1}{2}$ sulfate.

All the models assume highly acidic exopolymers with each monomer carboxylated. In nature, carboxylate concentration per monomer is lower, with uronic acid monomers forming less than 40 wt $\%$ of the total polysaccharide monomers (e.g., Brown and Lester 1980; Rougeaux et al. 2001; de Brouwer and Stal 2001). In nature, therefore, total EPS degradation should lead to more $\mathrm{CO}_{2}$ released relative to $\mathrm{Ca}^{2+}$ if compared to the model presented here.

The results of the model calculations show that the first step, decarboxylation and $\mathrm{Ca}^{2+}$ release, would cause a rise in $\mathrm{CaCO}_{3}$ supersaturation (Fig. 15). However, this rise is more than compensated by the simultaneous $\mathrm{CO}_{2}$ production from pentose decomposition in settings with DIC less than 16 mmol L$~^{-1}$ under aerobic conditions (Fig. 15B), $11 \mathrm{mmol} \mathrm{L}^{-1}$ upon fermentation, and $8 \mathrm{mmol} \mathrm{L}^{-1}$ upon sulfate reduction (Fig. 15C). In such settings, $\mathrm{CaCO}_{3}$ dissolution should be expected upon EPS decomposition. On the other hand, in settings with $>22 \mathrm{mmol} \mathrm{L}^{-1}$ DIC (Fig. 15B) and

TABLE 4.-Calculation of reef-top biofilm volume and estimated amount of $\mathrm{CaCO}_{3}$ deposited within the biofilms of June 1996.

\begin{tabular}{|c|c|c|c|c|c|c|c|}
\hline \multicolumn{2}{|c|}{ Reef Top Area } & \multirow[b]{2}{*}{ Roughness Factor } & \multirow[b]{2}{*}{$\begin{array}{c}\text { Estimated Total } \\
\text { Reef Top Area } \\
{\left[\mathrm{m}^{2}\right]}\end{array}$} & \multirow[b]{2}{*}{$\begin{array}{c}\text { Biofilm Thickness } \\
{[\mathrm{m}]}\end{array}$} & \multirow[b]{2}{*}{$\begin{array}{l}\text { Biofilm Volume } \\
{\left[\mathrm{m}^{3}\right]}\end{array}$} & \multirow[b]{2}{*}{ Calcified Fraction } & \multirow[b]{2}{*}{$\begin{array}{c}\mathrm{CaCO}_{3} \text { Deposited } \\
{\left[\times 10^{6} \mathrm{~g}\right]}\end{array}$} \\
\hline $\begin{array}{l}\text { Horizontal, Smooth } \\
\qquad\left[\mathrm{m}^{2}\right]\end{array}$ & $\begin{array}{l}\text { Vertical, Smooth } \\
{\left[\mathrm{m}^{2}\right]}\end{array}$ & & & & & & \\
\hline \multirow{3}{*}{16387} & \multirow{3}{*}{1885} & $2.69^{\mathrm{a}}$ & 49152 & \multirow{3}{*}{0.000542} & 26.64 & \multirow{3}{*}{0.27} & 21.22 \\
\hline & & $3.57^{\mathrm{b}}$ & 65231 & & 35.36 & & 28.16 \\
\hline & & $3.21^{\mathrm{c}}$ & 58653 & & 31.79 & & 25.32 \\
\hline
\end{tabular}

Density of aragonite $\rho=2.95 \mathrm{~g} / \mathrm{cm} / 3$. Roughness factors, average biofilm thickness, and calcified fraction has been determined by digital image analysis of 5 thin sections.

a Minimum roughness factor

Avximum roughness factor

Average roughness factor 

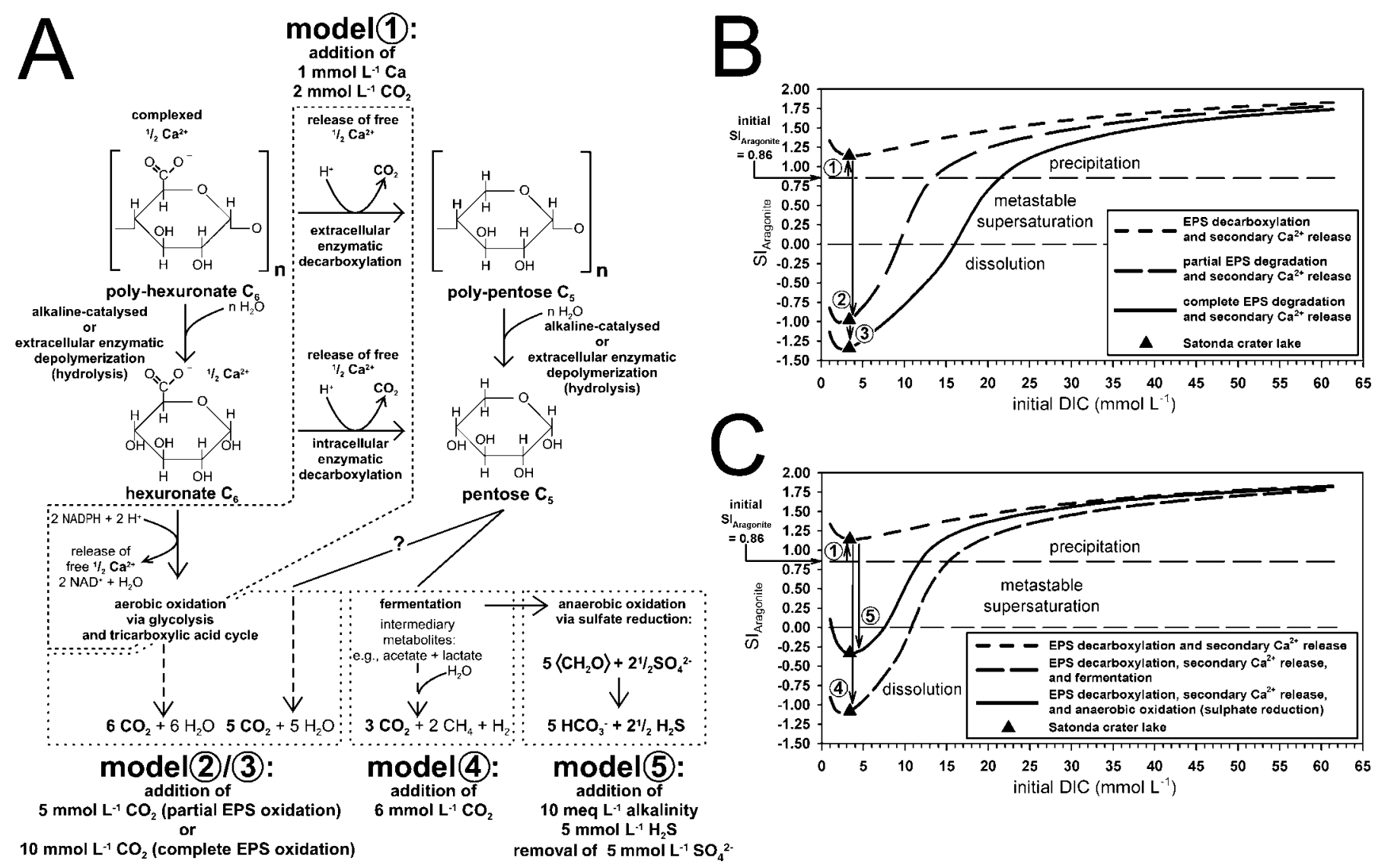

FIG. 15.-Theoretical effects on $\mathrm{CaCO}_{3}$ supersaturation upon degradation of EPS dominated by uronic acids. A) Simplified pathways of uronic acid degradation including decarboxylation, secondary $\mathrm{Ca}^{2+}$ release, and aerobic and anaerobic digestion of carbohydrate monomers. B) Calculated changes in aragonite supersaturation upon degradation of EPS in aerobic microenvironments. C) Calculated changes in aragonite supersaturation upon degradation of EPS in anaerobic microenvironments. The initial supersaturation $\left(\mathrm{SI}_{\text {Aragonite }}=0.86\right)$ is raised by decarboxylation because of liberated $\mathrm{Ca}^{2+}$ and $\mathrm{CO}_{2}$ and concomitant removal of $\mathrm{H}^{+}$from the water for charge balance (1). Ongoing aerobic and anaerobic digestion (2-5) of the remaining carbohydrate monomers leads to $\mathrm{CO}_{2}$ release, which is buffered as a function of dissolved inorganic carbon (DIC) concentration. As a result, waters with less than $8 \mathrm{mmol} \mathrm{L}^{-1}$ DIC, such as the Satonda mixolimnion water, become undersaturated with respect to CaCO 3 minerals upon EPS degradation.

$>12$ mmol L${ }^{-1}$ DIC (Fig. 15C) the released $\mathrm{CO}_{2}$ is effectively buffered, so that the significant rise in supersaturation of the first step is almost maintained. Thus, model results suggest that EPS degradation and secondary $\mathrm{Ca}^{2+}$ release would cause $\mathrm{CaCO}_{3}$ precipitation only in high-DIC/low$\mathrm{Ca}^{2+}$ settings such as typical highly alkaline soda lakes (Arp et al. 1998).

\section{DISCUSSION}

\section{Biofilm Calcification in Seawater of Raised Alkalinity}

Microbialites forming in recent lakes indicate that a level of supersaturation higher than that of the present ocean may be a prerequisite for biofilm calcifcation (Kempe and Kazmierczak 1990a). Indeed, it has been suggested that $\mathrm{CaCO}_{3}$ supersaturation of the ocean was higher during preTertiary times, and higher yet in the Precambrian (Kempe and Degens 1985; Kempe and Kazmierczak 1990a, 1994; Knoll et al. 1993; Grotzinger 1994). Thus, Satonda crater lake water, showing increased alkalinity and supersaturation, may serve as an analogue for ocean waters of certain time intervals prior to the Tertiary (Kempe and Kazmierczak 1994).

In Satonda crater lake, the causal process raising alkalinity is bacterial sulfate reduction in anoxic organic-rich sediments at the bottom of the lake (Kempe and Kazmierczak 1993). Major shifts in the carbonate equilibrium of the mixolimnion waters are driven by the seasonal hydrochemical cycle. This is demonstrated by the water-chemistry data of 1993 and 1996 (Table 1) and corresponding hydrochemical simulation (Table 3 ): mixis at the end of the dry season transfers alkalinity from the monimolimnion top layer to the mixolimnion. Upon $\mathrm{CO}_{2}$ degassing, $\mathrm{CaCO}_{3}$ supersaturation is raised above $\mathrm{SI}_{\text {Arag }}=0.86$ thereby causing $\mathrm{CaCO}_{3}$ precipitation. $\mathrm{H}_{2} \mathrm{~S}$ degassing appears negligible for the years 1993-1996 but may have been an additional factor in prior years when mixis reached deeper into the monimolimnion.

Mass-balance calculations demonstrate that the amount of $\mathrm{CaCO}_{3}$ that should have precipitated from a single mixis event and the amount of $\mathrm{CaCO}_{3}$ deposited within the reef-top biofilm are roughly of the same order of magnitude (Table 3, 4). For this calculation, the additional sink of $\mathrm{Ca}^{2+}$ in aragonitic and $\mathrm{Mg}$-calcitic skeletons of red algae, foraminifera, and gastropods were not taken into account. A slight surplus of $\mathrm{CaCO}_{3}$ actually deposited in the biofilms of 1996 (actually $25.32 \times 10^{6} \mathrm{~g}$, theoretically $21.63 \times 10^{6} \mathrm{~g}$ ) may reflect an additional supply of $\mathrm{CaCO}_{3}$ by intense endolithic activity. Because biofilms of these seasonally exposed reef tops are newly established each year, it appears unlikely that the difference between $25.32 \times 10^{6} \mathrm{~g}$ and $21.63 \times 10^{6} \mathrm{~g} \mathrm{CaCO}_{3}$ reflects an accumulation of precipitates of previous years. However, the actual area of the reef-top biofilm is difficult to determine, and error estimates indicate that current $\mathrm{CaCO}_{3}$ precipitates (1996) are in the range of 21 to $28 \times 10^{6} \mathrm{~g}$ (Table 4).

Recent carbonate precipitates were observed almost exclusively in reeftop biofilms in June 1996 at less than 0.9 m depth. Here, carbon fixation, and within microenvironments ammonification and sulfate reduction, potentially play a role in final promotion of precipitation. However, increased 
alkalinities and DIC limit the effect of any metabolic activity, especially photosynthesis, on the carbonate equilibrium because of buffering of the carbonate system (Arp et al. 2001). In the biofilms of the Satonda crater lake, the rare $\mathrm{CaCO}_{3}$ precipitates are linked neither to sheaths of living cyanobacteria nor to surfaces of filamentous green algae (e.g., Cladophora etc.). Also, bacterial microcolonies at the surface and within the biofilms are free of carbonate. Exceptions are three observations of semitubular aggregates around Calothrix trichomes and rare microcrystalline aggregates at the margin of Pleurocapsa colonies. Instead, most precipitates are located at the immediate contact with the open lake water. Thus, alkalinity and DIC of Satonda lake water effectively buffer the effect of photosynthetic carbon removal so that a sufficient rise in supersaturation within cyanobacterial sheaths is not achieved to induce an impregnation by $\mathrm{CaCO}_{3}$ $\left(\Delta \mathrm{SI}_{\mathrm{Cc}}<0.1\right.$; Arp et al. 2001).

Ammonification is expected to occur when substrates rich in nitrogen componds, such as dead metazoans, are available (Berner 1968, 1971). Although this may play a role in calcification of fecal pellets, the polysaccharide-rich biofilms dominated by photosynthetizing cyanobacteria are a less suitable substrate for this process because they are relatively low in nitrogen. Kazmierczak and Kempe (1990) and Kempe and Kazmierczak (1990a, 1993) suggested that sulfate reduction within decaying cyanobacterial biofilms may trigger aragonite precipitation in Satonda biofilms. This is an intriguing suggestion, but there are currently no investigations to support or disprove this hypothesis in Satonda. In situ hybridization would be necessary to demonstrate occurrence and distribution of sulfate-reducing activity within the biofilms (50-500 $\mu \mathrm{m}$ thick). Furthermore, microelectrode measurements $\left(\mathrm{O}_{2}, \mathrm{pH}, \mathrm{H}_{2} \mathrm{~S}\right)$ would help to monitor microbial activity. However, our model results of sulfate reduction on carbohydrates (Fig. 15A, C) suggest that simple addition of bicarbonate concurrently with $\mathrm{H}_{2} \mathrm{~S}$ production does not raise $\mathrm{CaCO}_{3}$ supersaturation. This is because $\mathrm{H}_{2} \mathrm{~S}$ production lowers $\mathrm{pH}$, thereby permitting the establishment of high $\mathrm{pCO}_{2}$ conditions within the sulfate-reduction zone. The Satonda monimolimnion is a typical example of this effect (Table 1).

Sufficient oxygenation of most biofilm parts, still often considered to limit sulfate reduction, is suggested by abundant living cyanobacteria and diatoms (cf. Van Gemerden 1993). However, several investigations have demonstrated clearly that sulfate reduction is not strictly restricted to anaerobic conditions, but also occurs - depending on the substrate type-in fully oxygenated environments, though commonly at less high rates (Canfield and Des Marais 1991; Fründ and Cohen 1992; Visscher et al. 1992). Even assuming significant sulfate-reducing activity under aerobic conditions in Lake Satonda biofilms, the strongly oxygenated conditions would eliminate any effect on the carbonate equilibrium because of instantaneous reoxidation of sulfide. Indeed, aerobic sulfate reduction could have been underestimated because of spontaneous sulfide oxidation hampering detection by radio tracers (Jørgensen 1994). Nonetheless, $\mathrm{CaCO}_{3}$ precipitation in biofilms enhanced by sulfate reduction may occur at night, when the $\mathrm{H}_{2} \mathrm{~S}$ produced diffuses upwards into the water column without immediate reoxidation by sulfide oxidizers (Visscher et al. 2000). Apart from that, there is a zone of abundant sulfate reducers within the reef carbonates. This zone is located $1-3 \mathrm{~cm}$ below the cyanobacterial reef-surface biofilms, as indicated by grayish and blackened reef framework voids. Here, it appears reasonable to expect anaerobic conditions raising alkalinity in the same way as in the lake-bottom waters.

Modeling of bacterial degradation of EPS demonstrates that decarboxylation (either extracellular or intracellular) and release of $\mathrm{Ca}^{2+}$ from EPS increases supersaturation (Fig. 15). However, in addition to decarboxylation, EPS degradation includes intracellular oxidation of the entire carbohydrate monomers after hydrolysis and depolymerization. Release of $\mathrm{CO}_{2}$ from partial or full digestion of these monomers in aerobic and anaerobic pathways lowers supersaturation (Fig. 15B, C). Finally, the total effect of EPS degradation on precipitation is dependent on the buffering effect of the carbon pool (Fig. 15B, C). In high-DIC settings, such as soda lakes, decarboxylation, $\mathrm{Ca}^{2+}$ release, and polysaccharide digestion indeed leads to a significant rise in supersaturation, promoting calcification (Arp et al. 1998). In turn, in settings with less than approximately 10 to $16 \mathrm{mmol}$ $\mathrm{L}^{-1}$ DIC (partial to complete EPS degradation) the total effect of aerobic EPS degradation causes undersaturation with respect to $\mathrm{CaCO}_{3}$ minerals (Fig. 15). The latter case applies to normal-marine settings $\left(2.18 \mathrm{mmol} \mathrm{L}^{-1}\right.$ DIC; Table 1), and also to the moderately alkaline Satonda mixolimnion waters (3.3-3.4 mmol L ${ }^{-1}$ DIC; Table 1). Thus EPS degradation is not considered to be a significant mechanism of carbonate precipitation in this lake.

Nucleation of $\mathrm{CaCO}_{3}$ crystals within biofilms takes place on macromolecules of EPS. Microcrystalline aragonite precipitates are interpreted to reflect a diffusion-controlled $\mathrm{Ca}^{2+}$ supply from the liquid phase that surpasses the $\mathrm{Ca}^{2+}$-binding capacity of the biofilm EPS in the alkaline, $\mathrm{CaCO}_{3}$-supersaturated environment. A random distribution of precipitates located at the immediate contact with open lake water results. In turn, it appears that the lack of $\mathrm{Ca}^{2+}$-complexing exopolymers within lysed greenalgal cells and subsurface reef framework voids permits rapid formation of the fibrous aragonite fans observed. Sulfate reduction within the pore water of reef carbonates may further raise alkalinity to promote growth of fibrous aragonite cement and (possibly) microcrystalline veneers within voids.

Lack of inhibiting exopolymers may also explain the formation of semiglobular, vesicular structures (Fig. 6A, B) described by Kazmierczak and Kempe (1990,1992) as representing a modern cyanobacterial counterpart of Wetheredella, a problematic microfossil frequently found in early $\mathrm{Pa}-$ leozoic reef microbialites (Riding 1991b). Kazmierczak and Kempe (1990, 1992) suggested that these fossils formed by high-Mg calcite permineralization of cell envelopes of Pleurocapsa. However, our observations indicate that organic-walled voids of similar size (200-270 $\mu \mathrm{m}$ wide, 70$130 \mu \mathrm{m}$ high) and shape represent resting bodies of the hadromerid sponge Laxosuberites (Fig. 13C). After degradation of the cells the EPS-free voids are favorable for growth of aragonite fans, similar to lysed green-algal cells as described above (Fig. 12B, D). Sections of recent material show that the organic walls of sponge cysts are unsuitable for $\mathrm{CaCO}_{3}$ nucleation (Fig. 13D). Therefore, aragonite fibers and botryoids were observed to originate only from the calcareous basal plane of the recent cysts. The resulting structures are identical to the subfossil, "Wetheredella-like" structures. It should be noted that the sharp outer boundary defined by an organic wall (Fig. 6B) is inconsistent with the previous interpretation of a high-Mg calcitic permineralized margin of Pleurocapsa colonies (Kazmierczak and Kempe 1990, 1992).

Discrepancies in the previous descriptions and results of Kazmierczak and Kempe (1990, 1992), Kempe and Kazmierczak (1990ab, 1993, 1994), and Kempe et al. $(1996,1997)$ exist with regard to biofilm composition, intensity of calcification, and inferred mechanism of precipitation. On the basis of samples taken in 1986 and 1993 they described an extensive development of biofilms composed of pleurocapsalean cyanobacteria, with their sheaths intensely $\mathrm{Mg}$-calcitic permineralized. We assume that the differences with our descriptions result from (1) possible changes in biofilm composition between 1986 and later, (2) collective assignment of different coccoid organisms (Pleurocapsa, Hyella, "Dermocarpella") to the cyanobacterium Pleurocapsa, and (3) the use of air-dried specimen for SEM imaging and EDX analysis (collapse of biofilm structures; Mg-containing precipitates from lake and pore water evaporation on air-dried specimen; mixed EDX signals from different mineral phases).

\section{Formation of Subfossil Microstromatolitic Crusts}

Calcification processes deduced from observations at recent Satonda reef surfaces, i.e., fibrous aragonite growth in EPS-poor places, smoothing of fibrous cements by corrosion, and microcrystalline impregnation of EPS at the contact with the liquid phase, support the development of a new model of subfossil microstromatolite formation in Satonda (Fig. 16). Microstro- 


\section{A: evaporation during dry season}

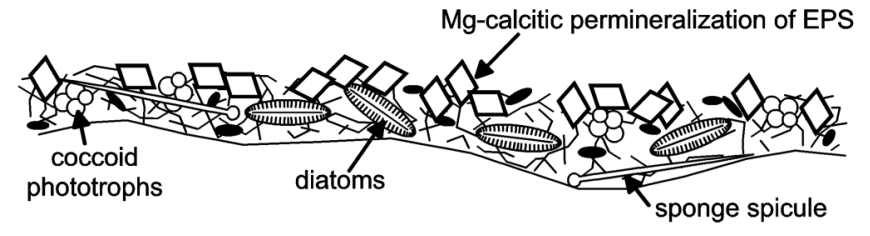

B: mixis at end of dry season, wet season

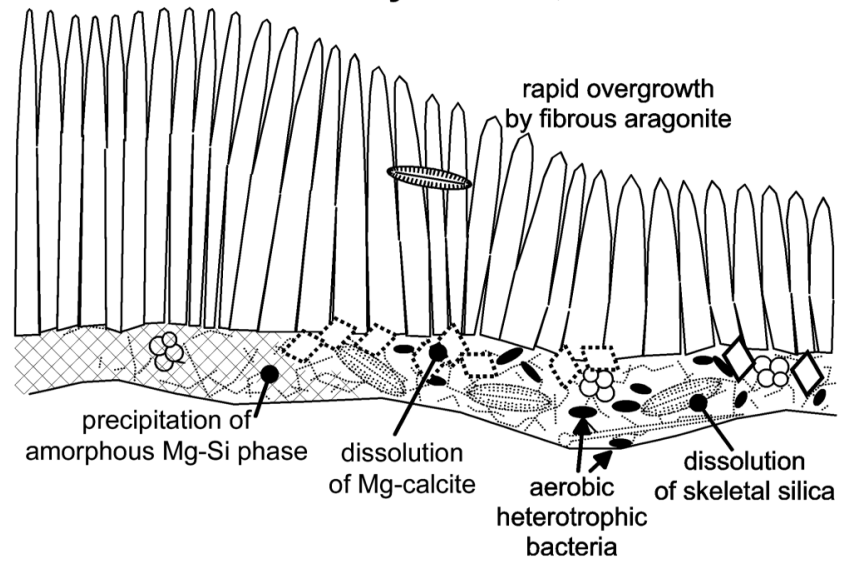

C: re-colonization at end of wet season

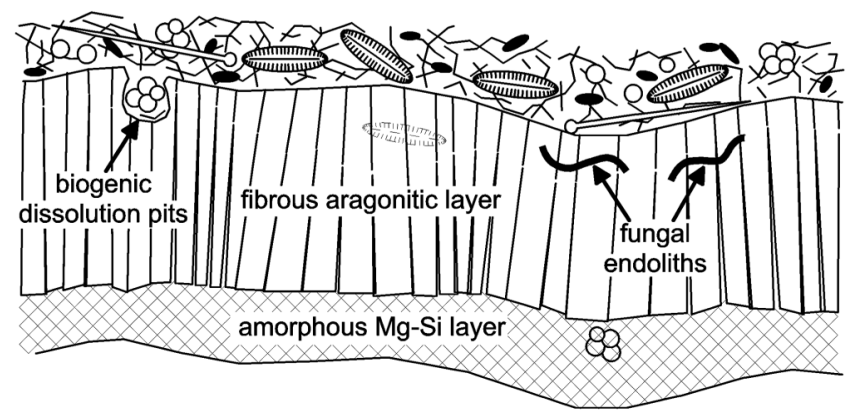

FIG. 16.-Model of microstromatolitic crust formation. A) Partial Mg-calcite impregnation of biofilms at the end of the dry season within successively evaporated mixolimnion water. B) Rapid growth of fibrous aragonite on top of calcified biofilm after seasonal mixis and $\mathrm{H}_{2} \mathrm{~S}$ and $\mathrm{CO}_{2}$ degassing. Dissolution of siliceous spicules and diatom tests at $\mathrm{pH}$ 8.6. C) Decomposition of EPS of entombed biofilm releases $\mathrm{CO}_{2}$, which causes a decrease in $\mathrm{pH}$, dissolution of $\mathrm{Mg}$-calcite, and simultaneous reprecipitation of silica to form an amorphous $\mathrm{Mg}-\mathrm{Si}$ phase. $\mathrm{Ca}^{2+}$ is removed completely and exported together with DIC to cause further aragonite growth upon equilibration of $\mathrm{pCO}_{2}$ to the bulk phase.

matolitic crusts of the subfossil green-algal microbialite formed within a bushy framework of Cladophora-type green-algal filaments. Traces of anhedral crystals within the amorphous $\mathrm{Mg}-\mathrm{Si}$ layers suggest that a primary carbonate mineral may have been replaced. Assuming high-Mg calcite, a quantitative removal of $\mathrm{Ca}^{2+}$ during silification is implied. Indeed, electron microprobe data of red-algal crusts indicate that some of the more recent Mg-calcitic Lithoporella layers are partially replaced by the amorphous $\mathrm{Mg}-\mathrm{Si}$ phase, whereas aragonitic thalli of Peysonnellia are not affected (Fig. 7). On the basis of this observation, a partially Mg-calcite impregnated biofilm is taken as the inital stage (Fig. 16A), which was subsequently replaced by the amorphous $\mathrm{Mg}-\mathrm{Si}$ phase. A less high $\mathrm{Mg} / \mathrm{Ca}$ ratio compared to the recent $\mathrm{Mg} / \mathrm{Ca}$ ratio of the lake water could explain that $\mathrm{Mg}$ calcite precipitation in addition to aragonite was common in the past in Satonda. This is consistent with the view that the present-day lake water of Satonda has evolved from seawater by a rise in alkalinity and successive deposition of $\mathrm{Ca}^{2+}$ in reef carbonates.

Overturn and mixis at the end of the dry season, when the density of evaporated surface water exceeds that of the water layers below, causes $\mathrm{Ca}^{2+}$ and alkalinity to be added from the monimolimnion to the mixolimnion. However, mixing events incorporating deeper water layers than during the past years must be assumed to account for the greater amount of $\mathrm{CaCO}_{3}$ deposited in each stromatolitic layer, if compared to recent biofilm calcification. A strong rise in $\mathrm{CaCO}_{3}$ supersaturation by subsequent $\mathrm{CO}_{2}$ and $\mathrm{H}_{2} \mathrm{~S}$ degassing is necessary to explain the rapid growth of fibrous aragonite at the surface of biofilms (Fig. 16B). This must have been fast because scattered diatom frustules are preserved, which would otherwise have been dissolved outside the carbonate crystals at a pH around 8.5-9.0. In turn, within the entombed biofilm siliceous skeletons, i.e., diatom tests and sponge spicules, should have been dissolved at the same $\mathrm{pH}$, because they were not previously enclosed within $\mathrm{CaCO}_{3}$ (Fig. 16B). The strong rise in $\mathrm{CO}_{3}{ }^{2-}$ supply during mixis may be one reason for a change from Mg-calcitic to aragonitic precipitation (Given and Wilkinson 1985), whereas a slight lowering in ionic strength due to addition of rain water would have had no effect (cf. Hardie 1987).

Following the rapid growth of external aragonite cement, the entombed biofilm was subject to decay (Fig. 16B). Upon heterotrophic decomposition of polysaccharide-dominated EPS (first aerobic, later anaerobic; Fig. 15), $\mathrm{pH}$ is lowered from the original alkaline conditions, which dissolved opal skeletons, to slightly acidic, thereby dissolving $\mathrm{CaCO}_{3}$ and reprecipitating $\mathrm{SiO}_{2}$ (Fig. 16B). Again, this must have been rapid to enclose organic remains of scattered coccoid microorganisms. The dissolved $\mathrm{Ca}^{2+}$ and DIC may have further enhanced aragonite growth upon diffusion to the cemented biofilm surface and equilibration to bulk-phase $\mathrm{pCO}_{2}$.

Finally, as seen in recent biofilms, the establishment of a new biofilm during the course of the next season on the surface of the fibrous aragonitic layer is suggested as the cause of surface smoothing of the fibrous aragonite layer, its dissolution pits, and thin borings by fungal and cyanobacterial endoliths (Fig. 16C). The dominance of fungal microborings suggests that fibrous aragonite layers might have formed in cryptic environments within the highly porous green-algal bioherms.

In general, the formation of microstromatolitic crusts upon green-algal tufts might have been triggered by the onset of the "alkalinity pump" in the Satonda Crater Lake (Kempe et al. 1996), and therefore may reflect the transition from normal-marine conditions to quasi-marine conditions of raised alkalinity. However, the model proposed herein contrasts with that of Kempe and Kazmierczak. Those authors suggested that the subfossil microstromatolites reflect a periodic in vivo calcification of superficial cyanobacterial layers by low-Mg calcite (Kempe and Kazmierczak 1990a, 1993) or high-Mg calcite and early post-mortem calcification of cyanobacterial aggregates below the mat surface by microbially precipitated aragonite (Kempe and Kazmierczak 1993; Kempe et al. 1996, 1997). However, within the microstromatolitic crusts there is no evidence for a former presence of cyanobacteria-dominated biofilms. Furthermore, electron microprobe measurements demonstrate that Mg-calcite layers of Kempe and Kazmierczak (1993) comprise $\mathrm{Mg}$ and $\mathrm{Si}$ in equal proportions, with $\mathrm{Ca}$ being absent (Fig. 4). Thus, a hydrated amorphous $\mathrm{Mg}-\mathrm{Si}$ phase is the mineral phase, possibly identical to an unidentified authigenic phase with a 1:1 molar ratio of $\mathrm{Mg}$ and $\mathrm{Si}$, which has been reported to form within sediments of, e.g., the Great Salt Lake (Spencer et al. 1985) and Lake Van (Reimer 1996).

\section{CONCLUSIONS}

(1) The quasi-marine setting of Satonda Crater Lake, characterized by increased alkalinity relative to normal marine seawater, currently permits aragonite precipitation in reef-surface biofilms because of a sufficiently high $\mathrm{CaCO}_{3}$ supersaturation $\left(\mathrm{SI}_{\mathrm{Cc}}=1.00\right.$ and $\mathrm{SI}_{\mathrm{Arag}}=0.86$, respectively). 
(2) Present precipitation of aragonite occurs in minor quantities and is restricted to cyanobacteria-dominated biofilms of seasonally exposed reef tops. The contribution of these $\mathrm{CaCO}_{3}$ precipitates to present reef growth is negligible.

(3) Diffusion-controlled, EPS-mediated permineralization of biofilms occurs at the contact with the lake water, resulting in micropeloidal aragonite clots. In addition, fibrous aragonite cements grow on surfaces poor in inhibiting mucus substances such as voids, lysed green-algal cells, and molds of hadromerid sponge resting bodies. Cementation of the latter results in the formation of "Wetheredella-like" structures.

(4) Hydrochemistry data and model calculations indicate that changes in carbonate equilibrium that lead to $\mathrm{CaCO}_{3}$ precipitation are externally driven by seasonal mixing of mixolimnion with monimolimnion waters and subsequent $\mathrm{CO}_{2}$ degassing. $\mathrm{H}_{2} \mathrm{~S}$ degassing, rain-water addition, and evaporation currently have little effect on $\mathrm{CaCO}_{3}$ precipitation.

(5) Hydrochemical model calculations indicate that the total effect of $\mathrm{Ca}^{2+}$ and $\mathrm{CO}_{2}$ release from decarboxylation and heterotrophic decomposition of acidic exopolysaccharides should cause $\mathrm{CaCO}_{3}$ dissolution in settings low or moderately high in dissolved inorganic carbon (i.e., less than approximately $16 \mathrm{mmol} \mathrm{L}^{-1} \mathrm{DIC}$ ). In turn, the total effect of the same processes promotes biofilm calcification in settings very high in DIC (i.e., more than approx. $22 \mathrm{mmol} \mathrm{L}^{-1}$ ).

(6) In Lake Satonda, moderately high alkalinity and DIC limit the influence of autotrophic microorganisms in biofilms on the carbonate equilibrium. As a result, $\mathrm{CaCO}_{3}$ precipitates spatially linked to photosynthetizing cyanobacteria are rare. Furthermore, aerobic heterotrophic activity lowers supersaturation in Satonda, despite release of $\mathrm{Ca}^{2+}$ from decarboxylation of acidic exopolymers.

(7) Subfossil microstromatolites are composed of alternating layers of an amorphous $\mathrm{Mg}-\mathrm{Si}$ phase and fibrous aragonite. They formed in the past when Lake Satonda was less depleted in $\mathrm{Ca}^{2+}$ than today, probably during times of more pronounced seasonality with stronger evaporation and deep mixis, balanced by an intense rainy season. The microstromatolites are explained by cyclic overgrowth of fibrous aragonite upon a $\mathrm{Mg}$-calcite impregnated biofilm. Within the entombed biofilms, opal of diatoms and spicules was dissolved at high $\mathrm{pH}$. In turn, the following aerobic heterotrophic decay of exopolymers caused a dissolution of Mg-calcite and reprecipitation of silica at lower $\mathrm{pH}$ to form an amorphous $\mathrm{Mg}-\mathrm{Si}$ layer.

\section{ACKNOWLEDGMENTS}

The study was supported by the Deutsche Forschungsgemeinschaft (SFB 468, Wechselwirkungen an geologischen Grenzflächen Teilprojekt A1, Re 665/12-1, 181, and Ke 287-9). GA sincerely thanks the Studienstiftung des deutschen Volkes for financial support (grant 9/95-4/97). Stephan Kempe, TU Darmstadt, is kindly acknowledged for controversial discussions on Satonda Crater Lake. We also wish to thank Günter Landmann, TU Darmstadt, for scientific cooperation, logistic organization, and diving support during the expeditions to Satonda. The Asian Wetland Bureau (W. Giesen and co-workers) and the rangers Alimuddin and Muhammad (Kantor KSDA Pulau Moyo) are gratefully acknowledged for support during field work. Electron microprobe measurements were performed by Andreas Kronz, Geowissenschaftliches Zentrum, Abteilung Geochemie, Göttingen. Helpful suggestions and corrections of two anonymous reviewers and Associate Editor Pamela Reid greatly improved the manuscript. We wish to thank the editors David A. Budd and John B. Southard for lingual improvements and comments.

The data described in this paper have been archived, and are available in digital form, at the World Data Center-A for Marine Geology and Geophysics, NOAA/ NGDC, 325 Broadway, Boulder, CO 80303; (Phone: 303-497-6339; fax: 303-4976513; E-mail: wdcamgg@ngdc.noaa.gov; URL: http://www.ngdc.noaa.gov/mgg/ sepm/archive/index.html.

\section{REFERENCES}

AdDadi, L., AND Weiner, S., 1985, Interactions between acidic proteins and crystals: stereochemical requirements in biomineralization: Proceedings of the National Academy of Sciences, U.S.A., v. 82, p. 4110-4114.

Arp, G., Hofmann, J., and Reitner, J., 1998, Microbial fabric formation in spring mounds ("microbialites") of alkaline salt lakes in the Badain Jaran Sand Sea, P.R. China: Palaios, v. 13, p. $581-592$.

Arp, G., Reitner, J., Wöhrheide, G., and Landmann, G., 1996, New data on microbial communities and related sponge fauna from the alkaline Satonda crater lake, in Reitner, J. Neuweiler, F., and Gunkel, F., eds., Global and Regional Controls on Biogenic Sedimentation. I. Reef Evolution. Research Reports: Göttinger Arbeiten zur Geologie und Paläontologie, Sonderband 2, p. 1-7.

Arp, G., ReImer, A., And Reitner, J., 1999b, Calcification in cyanobacterial biofilms of alkaline salt lakes: European Journal of Phycology, v. 34, p. 393-403.

Arp, G., Reimer, A., and Reitner, J., 2001, Photosynthesis-induced biofilm calcification and calcium concentrations in Phanerozoic oceans: Science, v. 292, p. 1701-1704.

Arp, G., Thiel, V., Reimer, A., Michaelis, W., and Reitner, J., 1999a, Biofilm exopolymers control microbialite formation at thermal springs discharging into the alkaline Pyramid Lake, Nevada, U.S.A.: Sedimentary Geology, v. 126, p. 159-176.

BERNER, R.A., 1968, Calcium carbonate concretions formed by the decomposition of organic matter: Science, v. 159, p. 195-197.

BERNER, R.A., 1971, Bacterial processes effecting the precipitation of calcium carbonate in sediments, in Bricker, O.P., ed., Carbonate Cements: Baltimore, The Johns Hopkins University, Studies in Geology, v. 19, p. 247-251.

Brant, D.A., AND Christ, M.D., 1990, Realistic conformational modeling of carbohydrates, in French, A.D., and Brady, J.W., eds., Computer Modeling of Carbohydrate Molecules: American Chemical Society, Symposium Series, v. 430, p. 42-68.

BROWN, M.J., AND LESTER, J.N., 1980, Comparison of bacterial extracellular polymer extraction methods: Applied and Environmental Microbiology, v. 40, p. 179-185.

Canfield, D.E., and Des Marais, D.J., 1991, Aerobic sulfate reduction in microbial mats: Science, v. 251, p. 1471-1473

Castanier, S., Le Métayer-Levrel, G., and Perthuisot, J.P., 2000, Bacterial roles in the precipitation of carbonate minerals, in Riding, R.E., and Awramik, S.M., eds., Microbial Sediments: Berlin, Springer-Verlag, p. 32-39.

Debon, S.J.J., AND TesTeR, R.F., 2001, In vitro binding of calcium, iron and zinc by non-starch polysaccharides: Food Chemistry, v. 73, p. 401-410

DE Brouwer, J.F.C., and Stal, L.J., 2001, Short-term dynamics in microphytobenthos distribution and associated extracellular carbohydrates in surface sediments of an intertidal mudflat: Marine Ecology Progress Series, v. 218, p. 33-44.

Decho, A.W., 1990, Microbial exopolymer secretions in ocean environments: Their role(s) in food webs and marine processes: Oceanography and Marine Biology: an Annual Review, v. 28, p. $73-153$.

Défarge, C., Trichet, J., Jaunet, A.M., Robert, M., Tribble, J., and Sansone, F.J., 1996, Texture of microbial sediments revealed by cryo-scanning electron microscopy: Journal of Sedimentary Research, v. 66, p. 935-947.

Dill, R.F., Shinn, E.A., Jones, A.T., Kelly, K., and Steinen, R.P., 1986, Giant subtidal stromatolites forming in normal salinity water: Nature, v. 324 , p. $55-58$

Dravis, J.J., 1983, Hardened subtidal stromatolites, Bahamas: Science, v. 219, p. 385-386

Fortin, D., FerRis, F.G., ANd Beveridge, T.J., 1997, Surface-mediated mineral development by bacteria: Reviews in Mineralogy, v. 35, p. 161-180.

FRÜND, C., AND Cohen, Y., 1992, Diurnal cycles of sulfate reduction under oxic conditions in microbial mats: Applied and Environmental Microbiology, v. 58, p. 70-77.

Gebelein, C.D., 1976, The effect of the physical, chemical and biological evolution of the Earth, in Walter, M.R., ed., Stromatolites: Amsterdam, Elsevier, Developments in Sedimentology, v. 20, p. 499-515.

GeitLer, L., 1932, Cyanophyceae: Rabenhorst's Kryptogamen-Flora von Deutschland, Österreich und der Schweiz, 2nd Edition: Koenigstein, Koeltz Scientific Books (Reprint 1985), v. $14,1196 \mathrm{p}$.

Given, R.K., AND Wilkinson, B.H., 1985, Kinetic control of morphology, composition and mineralogy of abiotic sedimentary carbonates: Journal of Sedimentary Petrology, v. 55, p. $109-119$.

Golubić, S., 1973, The relationship between blue-green algae and carbonate deposits, in Carr, N.G., and Whitton, B.A., eds., The Biology of Blue-Green Algae: Oxford, Blackwell, Botanical Monographs, v. 9, p. 434-472.

Golubić, S., AND CAMPBel, S.E., 1981, Biogenically formed aragonite concretions in marine Rivularia, in Monty, C.L.V., ed., Phanerozoic Stromatolites: Berlin, Springer-Verlag, p. 209-229.

Grotzinger, J.P., 1990, Geochemical model for Proterozoic stromatolite decline: American Journal of Science, v. 290-A, p. 80-103.

Grotzinger, J.P., 1994, Trends in Precambrian carbonate sediments and their implication for understanding evolution, in Bengtson, S., ed., Early Life on Earth: New York, Columbia University Press, p. 245-258.

Grotzinger, J.P., AND KNoll, A.H., 1995, Anomalous carbonate precipitates: is the Precambrian the key to the Permian?: Palaios, v. 10, p. 578-596.

HARDIE, L.A., 1987, Dolomitization-a critical view of some current views: Journal of Sedimentary Petrology, v. 57, p. 166-183.

HaRDIE, L.A., 1996, Secular variation in seawater chemistry: an explanation for the coupled secular variation in the mineralogies of marine limestones and potash evaporites over the past 600 m.y.: Geology, v. 24, p. 279-283.

JøRGENSEN, B.B., 1994, Sulfate reduction and thiosulfate transformation in a cyanobacterial mat during a diel oxygen cycle: FEMS (Federation of European Microbiological Societies) Microbiology Ecology, v. 13, p. 303-312.

KaLKowsKY, E., 1908, Oolith und Stromatolith im norddeutschen Buntsandstein: Zeitschrift der Deutschen Geologischen Gesellschaft, v. 60, p. 68-125.

Kawaguchi, T., And Decho, A.W., 2001, Potential roles of extracellular polymeric secretions (EPS) in regulating calcification. A study of marine stromatolites, Bahamas: Thalassas, $v$ 17, p. 11-19. 
KazmierczaK, J., and KemPe, S., 1990, Modern cyanobacterial analogs of Paleozoic stromatoporoids: Science, v. 250, p. 1244-1248.

KazmierczaK, J., and Kempe, S., 1992, Recent cyanobacterial counterparts of Paleozoic Wetheredella and related problematic fossils: Palaios, v. 7, p. 294-304

KelTs, K., AND Hsü, K.J., 1978, Freshwater carbonate sedimentation, in Lerman, A., ed., Lakes; Chemistry, Geology, Physics: New York, Springer-Verlag, p. 295-323.

Kempe, S., and Degens, E.T., 1985, An early soda ocean?: Chemical Geology, v. 53, p. 95 108.

Kempe, S., and KazmiercZaK, J., 1990a, Calcium carbonate supersaturation and the formation of in situ calcified stromatolites, in Ittekkot, V.A., Kempe, S., Michaelis, W., and Spitzy, A., eds., Facets of Modern Biogeochemistry: Berlin, Springer-Verlag, p. 255-278.

Kempe, S., and KazmierczaK, J., 1990b, Chemistry and stromatolites of the sea-linked Satonda Crater Lake, Indonesia: A recent model for the Precambrian sea?: Chemical Geology, v. 81, p. 299-310.

Kempe, S., and KazmierczaK, J., 1993, Satonda Crater Lake, Indonesia: Hydrogeochemistry and Bicarbonates: Facies, v. 28, p. 1-32.

Kempe, S., and KazmierczaK, J., 1994, The role of alkalinity in the evolution of ocean chemistry, organization of living systems, and biocalcification processes: Bulletin de l'Institut Océanographique Monaco, no. spéc. 13, p. 61-117.

Kempe, S., Kazmierczak, J., Reimer, A., Landmann, G., and Reitner, J., 1996, Microbialites and hydrochemistry of the Crater Lake of Satonda - a status report, in Reitner, J., Neuweiler, F., and Gunkel, F., eds., Global and Regional Controls on Biogenic Sedimentation. I. Reef Evolution. Research Reports: Göttinger Arbeiten zur Geologie und Paläontologie, Sonderband 2, p. 59-63.

Kempe, S., Kazmierczak, J., Reimer, A., Landmann, G., and Reitner, J., 1997, Satonda: a porthole view into the oceanic past, in Tomascik, T., Mah, A.J., Nontji, A., and Moosa, M.K., eds., The Ecology of Indonesian Seas: Jakarta, Periplus Editions, p. 156-166.

Knoll, A.H., Fairchild, I.J., AND SwetT, K., 1993, Calcified microbes in Neoproterozoic carbonates: Implications for our understanding of the Proterozoic/Cambrian Transition: Palaios, v. 8 , p. $512-525$.

KomÁreK, J., AND ANAGnostidis, K., 1986, Modern approach to the classification system of cyanophytes; 2-Chroococcales: Archiv für Hydrobiologie, Suppl. 73 (Algological Studies 43), p. 157-226.

Krumbein, W.E., 1979, Calcification by bacteria and algae, in Trudinger, P.A., and Swaine, D.J., eds., Biogeochemical Cycling of Mineral-Forming Elements: Amsterdam, Elsevier, Studies in Environmental Science, v. 3, p. 47-68.

Lowenstam, H.A., and Weiner, S., 1989, On biomineralization: Oxford, U.K., Oxford University Press, $324 \mathrm{p}$.

Lowenstein, T.K., Timofeeff, M.N., Brennan, S.T., Hardie, L.A., and Demicco, R.V., 2001, Oscillations in Phanerozoic seawater chemistry: evidence from fluid inclusions: Science, v. 294, p. 1086-1088

Lyons, W.B., Long, D.T., Hines, M.E., Gaudette, H.E., and Armstrong, P.B., 1984, Calcification of cyanobacterial mats in Solar Lake, Sinai: Geology, v. 12, p. 623-626.

Mackenzie, F.T., And Agegian, C.R., 1989, Biomineralization and tentative links to plate tectonics, in Crick, R.E., ed., Origin, Evolution, and Modern Aspects of Biomineralization in Plants and Animals: New York, Plenum Press, p. 11-27.

Mackenzie, F.T., And PigotT, J.D., 1981, Tectonic controls of Phanerozoic sedimentary rock cycling: Journal of the Geological Society London, v. 138, p. 183-196.

ManN, S., 1988, Molecular recognition in biomineralization: Nature, v. 322, p. 119-124.

Manz, W., Arp, G., Schumann-Kindel, G., Szewzyk, U., and Reitner, J., 2000, Widefield deconvolution epifluorescence microscopy combined with fluorescent in situ hybridization shows the spatial arrangement of bacteria in sponge tissue: Journal of Microbiological Methods, v. 40, p. 125-134.

Morse, J.W., AND MAcKenZIE, F.T., 1998, Hadean ocean carbonate geochemistry: Aquatic Geochemistry, v. 4, p. 301-319.

Nordstrom, D.K., Plummer, L.N., Wigley, T.M.L., Wolery, T.J., Ball, J.W., Jenne, E.A., Bassett, R.L., Crerar, D.A., Florence, T.M., Fritz, B., Hoffman, M., Holdren, G.R., Jr., Lafon, G.M., Mattigod, S.V., McDuff, R.E., Morel, F., Reddy, M.M., Sposito, G., and THRAILKILL, J., 1979, A comparison of computerized chemical models for equilibrium calculations in aqueous systems, in Jenne, E.A., ed., Chemical Modeling in Aqueous Systems, Speciation, Sorption, Solubility, and Kinetics: American Chemical Society, Symposium Series, v. 93, p. 857-892.

PARKhURST, D.L., 1995, User's guide to PHREEQC - a computer program for speciation, reaction-path, advective-transport, and inverse geochemical calculations: U.S. Geological Survey, Water-Resources Investigations, Report 95-4227, 143 p.

Paul, J., AND PerYt, T.M., 1999, Kalkowsky's stromatolites revisited (Lower Triassic Buntsandstein, Harz Mountains, Germany): Palaeogeography, Palaeoclimatology, Palaeoecology, v. 161, p. $435-458$

Paull, C.K., Chanton, J.P., Neumann, A.C., Coston, J.A., and Martens, C.S., 1992, Indicators of methane-derived carbonates and chemosynthetic organic carbon deposits: examples from the Florida Escarpment: Palaios, v. 7, p. 361-375.

Peckmann, J., Reimer, A., Luth, U., Luth, C., Hansen, B.T., Heinicke, C., Hoefs, J., And
ReITNER, J., 2001, Methane-derived carbonates and authigenic pyrite from northwestern Black Sea: Marine Geology, v. 177, p. 129-150

Pentecost, A., 1991, Calcification processes in algae and cyanobacteria, in Riding, R., ed. Calcareous Algae and Stromatolites: Berlin, Springer-Verlag, p. 3-20.

Reid, R.P., Visscher, P.T., Decho, A.W., Stolz, J.F., Bebout, B.M., Dupraz, C., Macintyre, I.G., Paerl, H.W., Pinckney, J.L., Prufert-Bebout, L., Steppe, T.F., and DesMarais, D.J., 2000, The role of microbes in accretion, lamination and early lithification of modern marine stromatolites: Nature, v. 406, p. 989-992.

Reimer, A., 1996, Hydrochemie und Geochemie der Sedimente und Porenwässer des hochalkalinen Van Sees in der Osttürkei: Doctoral thesis, Faculty of Geosciences, University of Hamburg, $123 \mathrm{p}$

Reitner, J., Gautret, P., Marin, F. and Neuweiler, F., 1995, Automicrites in a modern microbialite-Formation model via organic matrices (Lizard Island, Great Barrier Reef, Australia) Bulletin de l'Institut Océanographique Monaco, no. spéc. 14, p. 237-263.

RIDING, R., 1982, Cyanophyte calcification and changes in ocean chemistry: Nature, v. 299, p. 814-815.

Riding, R., 1991a, Classification of microbial carbonates, in Riding, R., ed., Calcareous Algae and Stromatolites: Berlin, Springer-Verlag, p. 21-51.

Riding, R., 1991b, Calcified cyanobacteria, in Riding, R., ed., Calcareous Algae and Stromatolites: Berlin, Springer-Verlag, p. 55-87.

RIDING, R., 2000, Microbial carbonates: the geological record of calcified bacterial-algal mats and biofilms: Sedimentology, v. 47, suppl. 1, p. 179-214.

Ritger, S., Carson, B., And Suess, E., 1987, Methane-derived autigenic carbonates formed by subduction-induced pore-water expulsion along the Oregon/Washington margin: Geological Society of America, Bulletin, v. 98, p. 147-156.

Rougeaux, H., Guezennec, M., Che, L.M., Payri, C., Deslandes, E., and Guezennec, J., 2001, Microbial communities and exopolysaccharides from Polynesian mats: Marine Biotechnology, v. 3, p. 181-187.

Royer, D.L., Berner, R.A., And BeERLing, D.J., 2001, Phanerozoic atmospheric $\mathrm{CO}_{2}$ change: evaluating geochemical and paleobiological approaches: Earth-Science Reviews, v. 54, p 349-392.

SANDBERG, P.A., 1983, An oscillating trend in Phanerozoic non-skeletal carbonate mineralogy: Nature, v. 305, p. 19-22.

SiKes, C.S., WierzBicki, A., AND Fabry, V.J., 1994, From atomic to global scales in biomineralization: Bulletin de l'Institut Océanographique Monaco, no. spéc. 14 (1), p. 1-47.

Simkiss, K., AND Wilbur, K.M., 1989, Biomineralization; Cell Biology and Mineral Deposition: San Diego, Academic Press, 337 p.

Spencer, R.J., and HaRdie, L.A., 1990, Control of seawater composition by mixing of river waters and mid-ocean ridge hydrothermal brines, in Spencer, R.J., and Chou, I.M., eds., Fluid-Mineral Interactions: a Tribute to H.P. Eugster: The Geochemical Society, Special Publication 2, p. 409-419.

Spencer, R.J., Eugster, H.P., and Jones, B.F., 1985, Geochemistry of Great Salt Lake, Utah II: Pleistocene-Holocene evolution: Geochimica et Cosmochimica Acta, v. 49, p. 739-747.

SuTHERLAND, I.W., 1977, Enzymes acting on bacterial surface carbohydrates, in Sutherland, I., ed., Surface Carbohydrates of the Prokaryotic Cell: London, Academic Press, p. 209-245.

Thompson, J.B., and Ferris, F.G., 1990, Cyanobacterial precipitation of gypsum, calcite, and magnesite from natural alkaline lake water: Geology, v. 18, p. 995-998.

TRICHET, J., AND DÉFARGE, C., 1995, Non-biologically supported organomineralization: Bulletin de l'Institut Océanographique Monaco, no. spéc. 14, p. 203-236.

Van Gemerden, H., 1993, Microbial mats: A joint venture: Marine Geology, v. 113, p. 3-25.

Visscher, P.T., Prins, R.A., AND van Gemerden, H., 1992, Rates of sulfate reduction and thiosulfate consumption in a marine microbial mat: FEMS (Federation of European Microbiological Societies) Microbiology Ecology, v. 86, p. 283-394.

Visscher, P.T., Reid, R.P., AND Bebout, B.M., 2000, Microscale observation of sulfate reduction: correlation of microbial activity with lithified micritic laminae in modern marine stromatolites: Geology, v. 28, p. 919-922.

Westbroek, P., De Jong, E.W., Van der Wal, P., Borman, A.H., De Vrind, J.P.M., KoK, D. De Brujun, W.C., AND Parker, S.B., 1984, Mechanisms of calcification in the marine alga Emiliania huxleyi: Philosophical Transactions of the Royal Society London, Series B, v 304 , p. $435-444$.

WiLKinson, B.H., 1979, Biomineralization, paleoceanography and the evolution of calcareous marine organisms: Geology, v. 7, p. 524-527.

WiLKINSON, B.H., AND Given, R.K., 1986, Secular variation in abiotic marine carbonates; constraints on Phanerozoic atmospheric carbon dioxide contents and oceanic $\mathrm{Mg} / \mathrm{Ca}$ ratios: Journal of Geology, v. 94, p. 321-333.

Wilkinson, B.H., OwEn, R.M., AND CARRoll, A.R., 1985, Submarine hydrothermal weathering, global eustasy, and carbonate polymorphism in Phanerozoic marine oolites: Journal of Sedimentary Petrology, v. 55, p. 171-183.

Wingender, J., Neu, T.R., And Flemming, H.C., EDS., 1999, Microbial Extracellular Polymeric Substances: Berlin, Springer-Verlag, $251 \mathrm{p}$.

Received 22 December 2000; accepted 10 July 2002. 